Ana Carla Batissoco

\title{
A conexina 26 e sua relação com outras proteínas no órgão de Corti
}


Ana Carla Batissoco

\section{A conexina 26 e sua relação com outras proteínas no órgão de Corti}

Tese apresentada ao Instituto de Biociências da Universidade de São Paulo, para a obtenção de Título de Doutor em Ciências, na Área de Biologia/Genética.

Orientadora: Profa. Dra. Regina Célia Mingroni Netto

Co-orientadora: Profa. Dra. Luciana Amaral Haddad

São Paulo 


\section{Ficha Catalográfica}

Batissoco, Ana Carla

A Conexina 26 e sua relação com outras proteínas no órgão de Corti

181 pp.

Tese (Doutorado) - Instituto de

Biociências da Universidade de São Paulo.

Departamento de Genética e Biologia Evolutiva.

1. GJB2

2.Conexina 26

3. Surdez hereditária

4. órgão de Corti

5. precipitação por afinidade de proteínas

6. células progenitoras

7. células de suporte

\section{Comissão Julgadora:}

$\operatorname{Prof}(\mathrm{a}) . \operatorname{Dr}(\mathrm{a})$.

$\operatorname{Prof}(a) \cdot \operatorname{Dr}(a)$.

$$
\operatorname{Prof}(a) \cdot \operatorname{Dr}(a) \text {. }
$$

$\operatorname{Prof}(\mathrm{a}) \cdot \operatorname{Dr}(\mathrm{a})$

Profa. Dra. Regina Célia Mingroni Netto

Orientadora 
Aos amores da minha vida; Alêe Urko. 


\section{Agradecimentos}

À minha orientadora Profa. Dra. Regina Célia Mingroni Netto, por sua dedicação, confiança e conselhos valiosos.

À minha co-orientadora Profa. Dra. Luciana Amaral Haddad, por toda orientação técnica e científica e pela grande disposição em me ajudar em todos os momentos desse estudo.

Aos meus pais, Luiz e Zulmira, e meus irmãos, Miguel e Graça, aos quais devo tudo o que sou.

Ao Alê pelo amor e apoio integral, ao Urko por ser a fonte de toda minha energia e a Ori, por todos os momentos de descontração.

Ao Prof. Dr. Paulo Otto, por ter me apresentado ao Laboratório de Genética Humana.

À Profa. Dra. Angela Vianna Morgante, pelo uso das dependências do laboratório de Genética Humana.

Ao Dr. Ignácio del Castillo pela amostra controle cedida para a triagem da deleção de $200 \mathrm{~Kb}$ localizada nas proximidades do gene GJB6 e pelas análises de MLPA.

Ao diretor da DERDIC (Divisão de Reabilitação dos Distúrbios da Comunicação, PUC-SP), Dr. Alfredo Tabith Jr. e ao diretor clínico Dr. Mauro Spinelli (in memoriam) e todos os demais membros do corpo profissional pelas inúmeras avaliações clínicas e audiológicas realizadas nos pacientes e seus familiares.

Aos amigos Faculdade de Medicina da USP, Jeanne, Luiz e Karina, pela amizade, pelo companheirismo e parceria na pesquisa e pelas ótimas discussões científicas e não científicas.

Aos funcionários e alunos do Laboratório de Genética Humana, de Genômica Funcional e de Oxidações Biológicas em Leveduras, que contribuíram de alguma forma para que eu realizasse este projeto. Em especial, agradeço à Maraísa pela amizade.

Aos meus colegas do laboratório de Genética Humana, Dayane, Magnólia, Renata e Vítor. Agradeço em especial a Lilian e a Maria Teresa pelo apoio técnico, científico e pela amizade. E também ao "agregado" Gustavo. E as ex-alunas Daniela e Renata Thiele. 
Aos meus amigos mais do queridos Deborah e Fernando, e também Crys, Larissa e Juliana por todo o apoio durante as aventuras e "desventuras" da vida acadêmica.

Aos funcionários do Departamento de Genética e Biologia Evolutiva e do Centro de Estudos do Genoma Humano pelo apoio técnico.

Ao Prof. Dr. Alberto A. G. F. C. Ribeiro, por ter permitido o acesso ao seu laboratório de Biologia Celular e Microscopia Eletrônica e em especial ao técnico Waldir Caldeira, por todos os longos períodos de captura de imagens.

À Ana Lucia Garippo, do núcleo de microscopia confocal/fluorescência Rede Multiusuários do Sistema FMUSP/HC pela captura de imagens e pelas valiosas dicas de imunofluorescência.

Aos nosso colaboradores internacionais, Prof. Stefan Heller (Department of Otolaryngology Head and Neck Surgery and Department of Molecular and Cellular Physiology, Stanford University School of Medicine, Stanford, Califórnia, USA) e Prof. Azel Zine (Institute for Neurosciences of Montpellier and Institute for Research in Biotherapy, University of Montpellier I, Montpellier, France) por todo o treinamento oferecido a nossa equipe de pesquisa em células-tronco/progenitoras do órgão de Corti.

Ao Prof. Dr. Ricardo Bento, pela coordenação dos projetos INCT-CNPq (Instituto Nacional de Ciência e Tecnologia de Células-Tronco) e RNTC-FAPESP (Rede Nacional de Terapia Celular), cujos recursos financieros permitiram parte das pesquisas aqui apresentadas.

À Profa. Dra. Mayana Zatz, pela coordenação dos projetos PRONEX-CNPq, CEPID-FAPESP, Centro de Estudos do Genoma Humano e INCT-CNPq, cujos recursos financeiros permitiram a execução da maioria das pesquisas aqui apresentadas

Ao Instituto de Biociências e ao Departamento de Genética e Biologia Evolutiva, pela infra-estrutura.

À FAPESP e CNPq pelos auxílio financeiro.

Aos nossos pacientes com deficiência auditiva e às suas famílias, pela enorme paciência em colaborar com nossas pesquisas.

A todos os animais sacrificados que contribuíram para esse estudo. 
SUMÁRIO

\begin{tabular}{lr}
\hline \hline Apresentação & 1 \\
\hline Resumo & 4 \\
\hline Abstract & 6 \\
\hline Capítulo 1 & 9 \\
\hline 1. Revisão bibliográfica & 9 \\
1.1.Introdução & 10 \\
1.2.Fisiologia da audição & 11 \\
1.2.1.O órgão de Corti & 13 \\
1.2.1.1.Desenvolvimento, proliferação e diferenciação celular no órgão de & 17 \\
1.2.1.2.A regeneração das células ciliadas como indicativo da presença de & 17 \\
células-tronco na orelha interna & 19 \\
1.3.Surdez de etiologia genética & 20 \\
1.4.Surdez não-sindrômica & 21 \\
1.5.Surdez não-sindrômica de herança autossômica recessiva e o lócus DFNB1 & 26 \\
1.6.As proteínas conexinas & 26 \\
1.6.1.Expressão e estrutura das conexinas & 28 \\
1.6.2.Funções das conexinas & 30 \\
1.6.3.Biossíntese das conexinas & 33 \\
1.6.4.Interação entre conexinas e outras proteínas &
\end{tabular}

\begin{tabular}{ll}
\hline Capítulo 2. Objetivos & 35
\end{tabular}

2.1. Objetivo geral 35

2.2. Objetivos específicos $\quad 35$

Capítulo 3. Pesquisa de novos alelos patogênicos no lócus DFNB1 relacionados à 36 surdez não-sindrômica de herança autossômica recessiva

3.1.Introdução

$\begin{array}{ll}\text { 3.2. Objetivo } & 37\end{array}$

3.3.Casuística e Métodos 38

3.3.1.Pacientes 38

3.3.2. Amostra controle 39 
3.3.3.1.Sequenciamento das regiões de código, promotora e de splicing do gene GJB2 GJB2

3.3.3.2. Triagem da deleção de $200 \mathrm{~kb}$ localizada nas proximidades do gene

3.3.3.3.Pesquisa de variações no número de cópias nos exons dos genes GJB2, GJB6, GJB3 e WFS1 por MLPA

3.4.Resultados

3.4.1.Sequenciamento das regiões de código, promotora e doadora de splicing do intron 1 do gene GJB2

3.4.2. Triagem da deleção de $200 \mathrm{~kb}$ a a $130 \mathrm{~kb}$ da região 5' do gene GJB6

3.4.3.Pesquisa de variações no número de cópias por MLPA e por PCR em tempo real quantitativa

3.5.Discussão

3.5.1.Sequenciamento das regiões de código, promotora e doadora de splicing do intron 1 do gene GJB2

3.5.2. Triagem da deleção de $200 \mathrm{~kb}$ localizada a $130 \mathrm{~kb}$ da região 5' do gene GJB6

3.5.3.Pesquisa de variações no número de cópias por MLPA (Multiplex Ligation-dependent Probe Amplification) e por PCR em tempo real quantitativa

Capítulo 4. Estabelecimento de culturas primárias de células neuro-epiteliais do órgão de Corti de cobaias e camundongos

4.1.Introdução

4.2. Objetivo

4.3.Animais e Métodos

4.3.1. Animais

4.3.2.Métodos

4.3.2.1.Dissecção do órgão de Corti de cobaias e camundongos neonatos

4.3.2.2. Cultura em suspensão de células progenitoras do órgão de Corti

4.3.2.3.Caracterização fenotípica das células em cultura

4.3.2.4. Contagem celular

4.3.2.5.Análises estatísticas

4.4.Resultados 
Capítulo 5. Pesquisa e identificação de proteínas que interagem com a Cx26

5.1.Introdução

5.2.Objetivo

5.3.Animais e Métodos

5.3.1. Animais

5.3.2.Métodos

5.3.2.1.Clonagem e expressão de uma proteína com a sequência codificadora para a região C-terminal da Cx26 em fusão com GST

5.3.2.2. Obtenção de proteínas recombinantes em condições solúveis ou insolúveis

5.3.2.3. Ensaios de precipitação por afinidade entre a proteína de fusão recombinante (GST-Cx26) e proteínas do lisado celular

5.3.2.4.Identificação proteica por espectrometria de massas

5.3.2.5.Análises in silico

5.4. Resultados

5.4.1. Clonagem e expressão de uma proteína com a sequência codificadora para a região C-terminal da Cx26 em fusão com GST

5.4.2.Ensaios de precipitação por afinidade entre as proteínas recombinantes e proteínas do lisado celular

5.4.3.Análises das proteínas identificadas por espectrometria de massas

5.5.Discussão 


\section{Índice de Figuras}

Figura 1.1. Esquema representando o aparelho auditivo humano: orelha externa (E), orelha média (M) e orelha interna (I).

Figura 1.2. Secção transversal de um dos giros da cóclea, mostrando sua divisão em três compartimentos longitudinais: as escalas vestibular, timpânica e média ou duto coclear.

Figura 1.3. Esquema ampliado do órgão de Corti, mostrando as células ciliadas internas e externas e as células de suporte.

Figura 1.4. Diferenciação das células progenitoras em células ciliadas e de suporte.

Figura 1.5. Representação esquemática dos genes GJB2 e GJB6.

Figura 1.6. Representação esquemática da região do lócus DFNB1, 13q12-11, onde estão presentes os genes GJB2 e GJB6 e das deleções descritas nessa região e associadas a surdez não-sindrômica de herança autossômica recessiva.

Figura 1.7. Representação esquemática da estrutura das conexinas, dos conexons e dos canais de junção do tipo fenda.

Figura 1.8. Representação esquemática da reciclagem dos íons potássio na cóclea.

Figura 1.9. Representação esquemática da síntese, montagem e degradação dos canais comunicantes do tipo fenda.

Figura 3.1. Representação esquemática do gene GJB2 e das suas regiões de código, promotora e doadora de splicing do intron 1 e da extensão das regiões sequenciadas nesse trabalho.

Figura 3.2. Exemplo de curva de dissociação específica mostrando um único pico máximo entre $80-84^{\circ} \mathrm{C}$.

Figura 3.3. Exemplo das curvas de amplificação das diluições seriadas utilizadas para a construção das curvas padrão e cálculo da eficiência dos pares de iniciadores quanto a sequência alvo.

Figura 3.4. Nova mutação p.L76P(c.C227T) no gene GJB2.

Figura 3.5. Resultados da genotipagem de SNPs com o MegaBace SNuPe Genotyping Kit da nova mutação p.L76P (c.C227T).

Figura 3.6. Triagem da deleção de $200 \mathrm{~kb}$ localizada a $130 \mathrm{~kb}$ da região 5 ' do 54 gene GJB6. 
Figura 3.7. Perfil das sondas de MLPA do kit SALSA P163-C1 Hearing loss no paciente em que foi detectada a duplicação do gene GJB2 associada à mutação 167 delT.

Figura 3.8. Gráficos mostrando a quantificação relativa $(\mathrm{QR})$ realizada a partir dos resultados da PCR em tempo real quantitativa no paciente controle sem duplicação e no paciente com a duplicação.

Figura 3.9. Representação esquemática do gene GJB2 e da região duplicada 59 detectada no DNA genômico do paciente portador da mutação c.167delT.

Figura 3.10. Heredograma da família da paciente portadora da mutação c.167delT no gene GJB2 em heterozigose e na qual foi detectada a duplicação na região de código do gene $G J B 2$.

Figura 3.11. Análise do alinhamento do resíduo 76 na conexina 26, do gene GJB2, em diferentes espécies.

Figura 4.1. Dissecção da orelha interna de cobaias.

Figura 4.2. Morfologia dos diferentes tipos de esferas obtidas de culturas de células em suspensão do órgão de Corti de camundongos.

Figura 4.3. Análise do potencial de proliferação das células do órgão de Corti de cobaias e camundongos em suspensão.

Figura 4.4. Resultado do ensaio de auto-renovação das células do órgão de Corti em suspensão.

Figura 4.5. Análise do número de células presentes nas otoesferas obtidas com o cultivo em suspensão das células do órgão de Corti de cobaias e camundongos em meio enriquecido com TGF $\alpha$ ou bFGF.

Figura 4.6 Imunofluorescência indireta com os anticorpos anti-nestina e antiSox2 nas otoesferas de cobaias e camundongos, após uma ou duas passagens, cultivadas na presença de bFGF or TGF $\alpha$.

Figura 4.7.: Imunofluorescência indireta com os anticorpos p27kip1 e Jagged 1 nas otoesferas de camundongos, após duas passagens, cultivadas na presença de TGF e submetidas a diferenciação celular.

Figura 4.8: Imunofluorescência indireta com os anticorpos miosina VIIa e Jagged 2, nas otoesferas de camundongos, após duas passagens, cultivadas na presença de TGF e submetidas a diferenciação celular.

Figura 5.1. Gráfico mostrando a variação da probabilidade de identificação correta de uma proteína pelo Scaffold 3 proteomic software, em função ao número de peptídeos identificados e probabilidade de identificação correta que reflete a porcentagem de similaridade. 
Figura 5.2. Triagem das colônias recombinantes com o vetor pGEX-4T-1.

Figura 5.3. Padronização das condições de expressão das proteínas GSTCx26 e GST.

Figura 5.4. Western blotting para confirmação da expressão das proteínas GSTCx26 e GST.

Figura 5.5. Solubilidade das proteínas GST-Cx26 e GST.

Figura 5.6. Quantificação e purificação das proteínas GST-Cx26 e GST.

Figura 5.7. Eletroforese em SDS-PAGE a 10\% dos precipitados ou sobrenadantes de ensaios de precipitação por afinidade com GST ou GSTCx26, tendo sido usada a extração de cérebro com o tampão PHEM.

Figura 5.8. Eletroforese em SDS-PAGE a 12\% dos precipitados ou sobrenadantes de ensaios de precipitação por afinidade com GST ou GSTCx26 tendo sido usada a extração de cérebro com os tampões EGTA e EDTA.

Figura 5.9. Eletroforese em SDS-PAGE a $8 \%$ dos precipitados ou sobrenadantes de ensaios de precipitação por afinidade com GST ou GSTCx26 tendo sido usada a extração de fígado com o tampão EGTA.

Figura 5.10. Eletroforese em SDS-PAGE a 8\% dos precipitados ou 115 sobrenadantes de ensaios de precipitação por afinidade com GST ou GSTCx26 tendo sido usada a extração de fígado com o tampão EGTA.

Figura 5.11. Diagrama de Venn mostrando as 23 proteínas candidatas a interagirem com a $\mathrm{Cx}-26$ classificadas em cinco grupos distintos de acordo com identidade de ontologia gênica relacionada a processo biológico, compartimento celular e função molecular. 


\section{Índice de Tabelas}

Tabela 1.1. Distribuição tecidual das conexinas (RNAm) em humanos (Cx $b s)$

e camundongos $(C x$ mus $)$.

Tabela 3.1. Relação das sondas que compõe o Kit SALSA MLPA P163 C1

(MRC - Holland) e as regiões cromossômicas abrangidas por elas.

Tabela 3.2. Programa de amplificação utilizado nos experimentos de PCR em tempo real.

Tabela 3.3. Sequência dos iniciadores de regiões diferentes do gene GJB2 utilizados nos experimentos de PCR em tempo real.

Tabela 3.4. Caracterização dos dezesseis pacientes com mutações monoalélicas nos genes GJB2 ou GJB6 e resultados das análises moleculares.

Tabela 3.5. Resultados das quantificações relativas (QR) das sequências alvo do gene GJB2, que indicam o seu número de cópias, e seus valores de $\mathrm{P}$ adotando-se intervalo de confiança de $95 \%$.

Tabela 4.1. Relação dos anticorpos primários utilizados na caracterização fenotípica das culturas de células progenitoras do órgão de Corti de cobaias e camundongos.

Tabela 4.2. Análise dos parâmetros obtidos quanto ao número de otoesferas e o número de células por otoesferas presentes no cultivo em suspensão de células do órgão de Corti de cobaias e camundongos, cujo meio de cultura foi enriquecido com TGF $\alpha$ ou bFGF.

Tabela 5.1. Relação das conexinas descritas por interagir com os domínios PDZs das proteínas ZO-1 e a sequência dos últimos dez resíduos da região Cterminal de cada para a espécie Mus musculus.

Tabela 5.2. Composição dos três diferentes tampões de lise utilizados para o ensaio de precipitação por afinidade.

Tabela 5.3. Sequência dos dez aminoácidos que compõem a região C106 terminal da Cx26 nas espécies Mus musculus e Homo sapiens.

Tabela 5.4. Relação dos 11 pares de fatias recortadas em geis de SDS-PAGE de concentrações diferentes referentes às bandas presentes no ensaio de interação por afinidade com a proteína de fusão GST-Cx26 e ausentes no ensaio com a GST.

Tabela 5.5. Relação do número de proteínas identificadas por meio da espectrometria de massas das 11 bandas isoladas em SDS-PAGE presentes apenas no ensaio de precipitação por afinidade com a proteína GST-Cx26 e das outras 11 bandas localizadas na mesma posição da canaleta vizinha correspondentes ao ensaio com a GST. 
Tabela 5.6. Relação total das 49 proteínas identificadas por meio da espectrometria de massa após análises com o Scaffold 3 proteomic software das 11 bandas recortadas de géis SDS-PAGE presentes no ensaio de precipitação por afinidade com a proteína GST-Cx26.

Tabela 5.7. Relação das 23 proteínas candidatas a interagirem com a região C-terminal da Cx26.

Tabela 5.8.: Classificação funcional baseada na literatura científica das 22 140 proteínas candidatas em potencial a participarem do complexo molecular da Cx26. 


\section{Sites utilizados para Análises in silico}

- DECIPHER: http://decipher.sanger.ac.uk/

- DGV - Database of Genomic Variants: http://projects.tcag.ca/variation/

- EMBL-EBI: http://www.ebi.ac.uk/

- Ensembl Genome Browser: http://www.ensembl.org/index.html

- ExPASy Proteomics server: http://expasy.org/

- Hereditary Hearing Loss Homepage-: http://hereditaryhearingloss.org/

- Kyte Doolittle Hydropathy:http://gcat.davidson.edu/rakarnik/KD.html

- MGI- Mouse Genome Informatic http://www.informatics.jax.org/

- NCBI :http://www.ncbi.nlm.nih.gov/

- POLYPHEM-2: http://genetics.bwh.harvard.edu/pph2/

- PSORT: http://psort.hgc.jp/

- The Connexin-Deafness Homepage : http://davinci.crg.es/deafness/

- SWISSPROT: http://www.ebi.ac.uk/uniprot/

- UCSC Genome Bioinformatics: http://genome.ucsc.edu/ 


\section{APRESENTAÇÃO}

Estimou-se que 16\% dos casos de surdez no Brasil, assim como 60\% nos países desenvolvidos, tenham causas genéticas. Desses, em $70 \%$ dos casos a surdez é não-sindrômica. Dos casos hereditários, 80\% têm herança autossômica recessiva. A causa mais comum de surdez não-sindrômica de herança autossômica recessiva são as mutações nos genes GJB2 e GJB6. Dentre os indivíduos com deficiência auditiva recessiva associada ao gene GJB2, 10\% a 50\% apresentam uma única mutação recessiva em heterozigose detectável por testes convencionais, frequência muito superior à esperada com base na frequência de heterozigotos na população geral.

Durante o projeto de mestrado que teve o objetivo de caracterizar os tipos e estimar a frequência das mutações dos genes GJB2 e GJB6 (lócus DFNB1), que codificam para as proteínas conexinas 26 e 30, respectivamente, estudamos uma amostra de 300 indivíduos com perda auditiva e sem diagnóstico de síndrome conhecida associada à surdez. Foram rastreadas as mutações c.35delG e c.167delT no gene GJB2, del(GJB6-D13S1830) e $\operatorname{del}(G J B 6-\mathrm{D} 13 S 1854)$ no gene GJB6, e polimorfismos conformacionais de fita simples (SSCP) no gene GJB2, para posterior identificação de mutações por sequenciamento. A mutação c.35delG no gene GJB2 foi a mais frequentemente detectada, presente em 37 indivíduos $(12,4 \%)$, sendo 22 homozigotos e 15 heterozigotos. Entre os heterozigotos, em oito (53,3\%) não foi identificada uma segunda mutação no gene GJB2 ou no GJB6. Desde então, mais 8 indivíduos com situação semelhante foram identificados em nosso serviço de aconselhamento genético, totalizando 16 casos.

A maioria dos trabalhos sobre mutações no gene GJB2 investigam sua região codificadora e a região não codificadora foi pouco estudada. Alguns estudos já revelaram mutações fora da região de código do gene que afetam o padrão de splicing do RNA mensageiro ou o seu nível de expressão. O alto número de surdos portadores de uma única mutação recessiva (sem a segunda mutação detectada) sugere que a haplo-insuficiência no gene GJB2 possa interagir com outras mutações no mesmo gene, no gene GJB6 vizinho ou até em outros genes. 
A triagem de variantes patogênicas no gene GJB2 fora de sua região código, bem como o estudo de grandes deleções, a exemplo das que ocorrem com o seu gene vizinho, o GJB6, pode nos auxiliar a revelar os mecanismos moleculares que relacionam os produtos desses dois genes, GJB2 e GJB6, além de poder explicar os casos de pacientes surdos com uma única mutação detectada no gene GJB2. Para dar continuidade aos estudos iniciados no mestrado e também contribuir para o esclarecimento da patogênese da surdez de herança autossômica recessiva, o nosso primeiro objetivo no doutorado foi a identificação de novos alelos patogênicos no lócus DFNB1 (onde estão contidos os genes GJB2 e GJBG) que possam ser responsáveis por surdez quando presentes com outros alelos patogênicos nos genes GJB2 e GJB6, no material genético de pacientes surdos, previamente caracterizados como portadores de uma única mutação recessiva patogênica.

$\mathrm{Na}$ orelha interna, mais especificamente na cóclea, o órgão de Corti, estrutura responsável pela transdução do som em impulsos nervosos, é formado por dois tipos celulares altamente diferenciados, as células ciliadas (internas e externas) e as células de suporte. Uma característica marcante destas células é que, durante o desenvolvimento embrionário, elas entram em diferenciação terminal e são mantidas em quiescência mitótica ao longo da vida. Em aves, peixes e anfíbios, as células ciliadas auditivas são capazes de se regenerarem após lesão celular como parte do processo fisiológico de crescimento e manutenção tecidual, devido à proliferação e transdiferenciação das células de suporte. Já em mamíferos, a perda das células ciliadas auditivas é definitiva, representando uma das principais causas de surdez em seres humanos. Recentemente, foi demonstrado que células ciliadas do órgão de Corti podem ser obtidas a partir de células-tronco embrionárias e de células-tronco adultas da orelha interna, da medula óssea e neurais dos camundongos. Essas células são multipotentes e, em teoria, capazes de originar todos os tipos celulares da orelha interna. Dada à extrema relevância do tema, o cultivo das células do órgão de Corti em laboratório representa um passo fundamental, não somente para o desenvolvimento de futuras terapias gênicas e celulares, mas também para desvendar os mecanismos moleculares e celulares relacionados à fisiologia da audição e, consequentemente, à sua perda. Assim, buscando realizar pesquisas 
básicas sobre audição e alternativas ao tratamento da surdez foi formado, em 2007, um grupo de pesquisa com integrantes do Instituto de Biociências da USP e do Departamento de Oftalmologia e Otorrinolaringologia da Faculdade de Medicina da USP, com o objetivo de estabelecer no Brasil condições para pesquisa básica e clínica sobre audição, com ênfase no cultivo e no estudo de células do órgão de Corti. Uma vez que a conexina 26, proteína codificada pelo GJB2, é expressa nas células de suporte do órgão de Corti, o cultivo dessas células em laboratório representa passo de fundamental importância em estudos básicos de identificação e localização de proteínas, relacionadas à função auditiva. Desse modo, o segundo objetivo do projeto de doutorado foi padronizar protocolos para cultivo e diferenciação de células epiteliais do órgão de Corti de cobaias e camundongos, para se criar, a médio prazo, condições experimentais fundamentais aos estudos funcionais relacionados às conexinas e suas "parceiras" e, a longo prazo, ao desenvolvimento de estratégias futuras de terapia celular e terapia gênica na deficiência auditiva.

Diversos estudos têm sido realizados com o objetivo de demonstrar a interação entre conexinas e outras proteínas, como as proteínas de zônula de oclusão-1 (ZO-1 ou TJP1), as calmodulinas, as caderinas, algumas cinases e proteínas do citoesqueleto. No entanto, até o momento, são poucas as proteínas identificadas por interagirem com a Cx26. A identificação de proteínas que se associam com a Cx26 amplia a base de nosso conhecimento funcional das conexinas e indica novos genes candidatos como causa de surdez sindrômica e nãosindrômica, que poderiam vir também a explicar os casos de pacientes surdos com uma única mutação no gene GJB2. Estes casos poderiam ser explicados por herança digênica, ou seja, interação gênica entre o loco da Cx26 e outro que codifique para outra proteína, que se associa a ela física e funcionalmente. Desse modo, o terceiro objetivo do nosso estudo foi identificar proteínas que interagem com a $\mathrm{Cx} 26$, em diferentes tecidos que a expressam e também nas células de suporte do órgão de Corti. Desta forma, pretende-se aprofundar o conhecimento sobre as vias funcionais relacionadas à audição. 


\section{RESUMO}

A causa mais frequente de surdez de herança autossômica recessiva são as mutações no lócus DFNB1, onde estão os genes GJB2 e GJB6. Dentre os indivíduos com deficiência auditiva associada a esse lócus, $10 \%$ a $50 \%$ apresentam uma única mutação recessiva no gene GJB2, frequência muito superior à esperada em função da frequência de heterozigotos na população geral. Apesar de alguns desses casos terem sido elucidados após a identificação de grandes deleções no gene GJB6 ou nas suas proximidades, a existência de muitos indivíduos com uma única mutação patogênica no gene GJB2 sugere que a haplo-insuficiência nesse gene possa interagir com outras mutações no mesmo gene, no gene GJB6 vizinho, ou até em outros genes.

O objetivo desse estudo foi identificar novos alelos patogênicos, novas proteínas e novos genes que interagem com o lócus DFNB1, do ponto de vista molecular e celular, e que possam ser responsáveis por surdez de herança autossômica recessiva. Desse modo, pretendemos contribuir para o esclarecimento da patogênese da surdez de herança autossômica recessiva. Nesse trabalho, três tipos de estudos foram realizados, com metodologias próprias.

$\mathrm{Na}$ primeira parte, buscamos identificar novos alelos patogênicos no lócus DFNB1 que poderiam ser responsáveis por surdez quando presentes em heterozigose composta com outros alelos patogênicos nos genes GJB2 e GJB6. Foi realizada a análise do DNA de 16 pacientes surdos portadores de uma única mutação patogênica em um desses dois genes por meio: (i) do sequenciamento das regiões codificadora, promotora e doadora de splicing (intron 1) do gene GJB2, (ii) da triagem de uma deleção de $200 \mathrm{~kb}$ localizada a $130 \mathrm{~kb}$ da proximidade distal da região 5' do gene GJB6 e (iii) da pesquisa de variações no número de cópias de um ou mais exons dos genes GJB2, GJB6, GJB3 e WFS1 por MLPA (Multiplex Ligationdependent Probe Amplification). Detectamos uma segunda mutação provavelmente patogênica em dois dos 16 pacientes heterozigotos: em um deles, a mutação p.L76P (c.C227T) foi identificada na região de código do gene GJB2 e foi por nós descrita 
pela primeira vez; no segundo caso, uma duplicação $(0,4-1,2 \mathrm{~Kb})$ que inclui a região de código do gene GJB2 foi detectada, também inédita na literatura.

$\mathrm{Na}$ segunda parte, tivemos como objetivo obter um modelo experimental para estudos funcionais in vitro da proteína codificada pelo gene GJB2, a conexina 26, em seu local de expressão que são as células de suporte do órgão de Corti. Padronizamos o cultivo in vitro de células progenitoras do órgão de Corti de camundongos e de cobaias e conseguimos obter a diferenciação in vitro das otoesferas dos camundongos em células que expressam marcadores de células ciliadas (Miosina VIIa e Jagged2) e de células de suporte (p27kip e Jagged1).

Por fim, na terceira parte, buscamos por proteínas que interagem com a conexina 26 por meio de ensaios de precipitação por afinidade. Para isso, produzimos clones recombinantes de uma proteína de fusão GST-Cx26 e de uma proteína controle (GST), e realizamos sua expressão in vitro em bactérias E.coli B21. Ensaios de precipitação por afinidade entre a proteína de fusão GST-Cx26 ou GST sozinha e proteínas extraídas de cérebro ou fígado de camundongos foram realizados em diferentes condições. A identificação e a análise das proteínas presentes em bandas de SDS-PAGE, obtidas no ensaio de precipitação com a proteína de fusão GST-Cx26 e ausentes no ensaio com a GST, foi realizada por espectrometria de massas. Identificamos um total de 49 proteínas candidatas a interagirem com a região C-terminal da Cx26. Realizamos diversas análises in silico e em literatura específica e após exclusão de candidatas por: (i) redundância de representação no ensaio GST-Cx26, (ii) diferença entre a massa molecular esperada e a obtida, (iii) precipitação inespecífica e (iv) localização subcelular incompatível com a conexina 26, selecionamos um total de 22 proteínas candidatas a interagirem com a região C-terminal da conexina 26, para estudos futuros. A confimação da interação entre essas 22 proteínas e a conexina 26 é desejável por meio de estudos de co-localização e imuno-coprecipitação. 
The most frequent causes of nonsyndromic recessive hearing loss are mutations in locus DFNB1, in the GJB2 and GJB6 genes. Among the individuals with hearing loss with mutations in this locus, $10 \%$ to $50 \%$ present a single recessive mutation in the GJB2 gene, frequency much higher than expected taking into account the frequency of heterozygotes in the general population. Although some of these cases have been elucidated after the identification of large deletions in GJB6 or its surrounding regions, the existence of many individuals with a single pathogenic mutation in the GJB2 gene suggests that haplo-insufficiency of this gene may interact with other types of mutations in the same gene, in the neighbor gene GJB6, or even in other genes.

The aim of this study was to identify new pathogenic alleles, proteins and genes that interact with the locus DFNB1, from the molecular and cellular perspective, and that may be responsible for autosomal recessive deafness. Thus, we aimed to contribute to the understanding of the pathogenesis of autosomal recessive deafness. In this work, three different types of studies were performed, each one with a particular methodology.

In the first part, we searched for new pathogenic alleles in the locus DFNB1 that could be responsible for deafness, when present in compound heterozygosis with other pathogenic alleles in GJB2 and GJB6 genes. We performed DNA analysis in samples from 16 deaf patients, carriers of a single pathogenic mutation in one of these two genes by: (i) sequencing the coding, promoter and splice donor (intron 1) regions of the GJB2 gene, (ii) screening for a deletion of $200 \mathrm{~kb}$ located $130 \mathrm{~kb}$ upstream from $G J B 6$ gene and (iii) investigating copy number variations in of one or more exons of the genes GJB2, GJB6, GJB3 and WFS1 by MLPA (Multiplex Ligation-dependent Probe Amplification). We detected a second mutation, probably pathogenic, in two of the 16 heterozygous patients: in one case, the p.L76P (c.C227T) mutation was identified in the coding region of the GJB2 gene and was 
firstly described by us; in the second case, a novel duplication $(0.4-1.2 \mathrm{Mb})$ that includes the coding region of the GJB2 gene was detected.

In the second part, our objective was to obtain an experimental model for in vitro functional studies of the protein encoded by the GJB2 gene, connexin 26, in its site of expression, that is, in the supporting cells of the organ of Corti. We standardized the culturing of guinea pigs and mice progenitor cells of organ of Corti. We were also able to induce differentiation of mice's otospheres into cells that express markers of hair (myosin VIIa and Jagged2) and supporting cells (p27kip and Jagged1).

Finally, we searched for connexin 26 interacting proteins by pull-down assays. Recombinant clones expressing a fusion protein GST-Cx26 and a control protein (GST) were produced, so that in vitro expression in E. coli B21 could be performed. Pull-down experiments, perfomed with fusion protein GST-Cx26 or GST alone, and with proteins from mice brain or liver extracts were done under several different conditions. The identification and analysis of proteins present in SDS-PAGE bands in experiments performed with the fusion protein GST-Cx26, and absent in the GST assay, were performed by mass spectrometry. We identified a total of 49 candidate proteins for interaction with the C-terminal region of $\mathrm{Cx} 26$. In silico analyses performed in several databases and search in the literature allowed exclusion of candidates by: (i) redundancy of representation in the GST-Cx26 experiments; (ii) discrepancy between the expected and the obtained molecular weight; (iii) nonspecific precipitation and (iv) subcellular localization incompatible with connexin 26 localization. Summing up, we selected a total of 22 candidate proteins to interact with the C-terminal region of connexin 26. Confirmation of the interaction between these proteins and connexin 26 is planned to be performed by co-localization studies and by immuno-coprecipitation. 
Capítulo 3 


\section{CAPÍtUlu 3}

Pesquisa de novos alelos patogênicos no lócus DFNB1 relacionados à surdez não-sindrômica de herança autossômica recessiva

\subsection{Introdução}

Dentre os indivíduos com deficiência auditiva associada ao lócus DFNB1, 10\% a 50\% apresentam uma única mutação recessiva no gene GJB2, frequência muito superior à esperada em função da frequência de heterozigotos na população geral. Apesar de alguns casos de indivíduos com distúrbios de audição que apresentam uma única mutação recessiva no gene GJB2 terem sido elucidados após a identificação de cinco diferentes deleções no gene GJB6 ou nas suas proximidades (del Castillo e col., 2003, 2005 e 2009; Feldmann e col., 2009; Wilsh e col., 2010) a existência de muitos indivíduos com uma única mutação patogênica nesse gene sugere que mutações em outras regiões do lócus DFNB1, como por exemplo em outras regiões do gene GJB2, GJB6, fora da sua região de código, possam estar presentes de forma a causar a surdez desses indivíduos. Diversos estudos têm procurado identificar mutações nas regiões 5’UTR (no exon 1 e no sítio doador de splicing) e nas regiões promotoras do gene GJB2. Um exemplo é a mutação IVS $1+$ $1 \mathrm{G}>\mathrm{A}$, localizada no primeiro intron do gene GJB2, entre o exon 1 não codificador e o exon 2, no sítio doador de splicing. A troca de uma guanina por uma adenina nessa posição afeta o splicing e leva, aparentemente, à falta do RNA mensageiro (Denoyelle e col., 1999; Shahin, 2002). O estudo dessa mutação, por Seeman e col. (2006), possibilitou o diagnóstico molecular de 45\% de uma amostra de pacientes tchecos com uma única mutação patogênica na região codificadora do gene GJB2. Já na Holanda, onde ela também foi estudada, a mutação IVS $1+1 G>$ A foi apontada como a terceira mutação mais frequente em indivíduos surdos, após a c.35delG e a $\operatorname{del}(G J B 6-\mathrm{D} 13 \mathrm{S1830})$ (Santos e col., 2005). Outros estudos descreveram essa mutação em diversos países (Áustria, China, EUA, Egito, Itália, Irã, Hungria e Turquia) (Najmabadi e col., 2005; Snoeckx e col., 2005; Sirmaci e col., 2006; Chaleshtori e col., 2007; Putcha e col, 2007; Ramsebner e col., 2007; Tóth e col., 2007; Cama e col., 2009; Yuan e col., 2010). No Brasil, Silva-Costa e col. (2009) 
identificaram a mutação IVS $1+1 \mathrm{G}>\mathrm{A}$ em 2 dos $43(4,6 \%)$ pacientes surdos já previamente caracterizados como portadores de uma única mutação recessiva na região codificadora do gene GJB2.

Mattos e col. (2007) identificaram pela primeira vez uma mutação patogênica na região promotora do gene GJB2 associada à surdez não-sindrômica de herança autossômica recessiva em uma família portuguesa. Essa mutação, -3438C >T, foi identificada em trans com a mutação patogênica p.V84M.

A existência do alto número de indivíduos com uma única mutação patogênica recessiva nos genes GJB2 e GJB6 sugere que outras mutações não identificadas no lócus DFNB1 possam estar presentes de forma a causar surdez nesses indivíduos. A triagem de variantes patogênicas no gene GJB2, fora de sua região codificadora, bem como o estudo de grandes deleções ou inserções, a exemplo das que ocorrem com o gene GJB6, podem nos auxiliar a revelar os mecanismos moleculares que relacionam os produtos dos genes GJB2 e GJB6, além de poder explicar os casos de pacientes surdos com uma única mutação detectada no gene GJB2.

\subsection{Objetivo}

Identificar novos alelos patogênicos no lócus DFNB1 que possam ser responsáveis por surdez, quando presentes em heterozigose composta com outros alelos patogênicos nos genes da Cx26 ou Cx30.

Para atingir esse objetivo, foram executadas as seguintes etapas:

- Pesquisa de mutações por meio do sequenciamento das regiões codificadora, promotora e doadora de splicing (intron 1) do gene GJB2 nos pacientes previamente caracterizados como portadores de uma única mutação patogênica e recessiva nos genes GJB2 ou GJB6.

- Pesquisa da deleção de 200kb descrita por del Castillo e col., (2009), localizada a $130 \mathrm{~kb}$ da proximidade distal da região 5' do gene GJB6 em pacientes 
autossômica dominante. Em um desses pacientes (paciente 10, Tabela 3.4.) foi posteriormente detectada uma mutação patogênica não descrita no gene TECTA, responsável por surdez não-sindrômica de herança autossômica dominante (DFNA8/12) que segrega na família (Lezirovitz e col., 2011). Desse modo, concluímos que as mutações c.35delG e c.167delT no gene GJB2 e a delGJB6(D13S1854) no gene GJB6 nesses sete pacientes ( 7 a 10,12, 15 e 16) ocorreram ao acaso e não explicam o quadro clínico apresentado por esses indivíduos. Entre esses sete pacientes, quatro (pacientes 7 a 10) apresentam a mutação c.35delG em heterozigose. Dado que a frequência de heterozigotos para a mutação c.35delG na nossa população foi estimada em 1/100 (Sartorato e col., 2000), e que o tamanho da casuística do laboratório é de cerca de 700 pacientes, em teoria sua ocorrência está de acordo com o esperado para nossa população.

\subsection{Conclusão}

Detectamos a segunda mutação provavelmente patogênica apenas em dois dos nossos 16 pacientes heterozigotos quanto a mutações patogênicas e recessivas nos genes GJB2 ou GJB6: a mutação p.L76P, localizada na região de código do gene GJB2 descrita por nós pela primeira vez e uma duplicação que inclui a região de código do gene GJB2, também inédita na literatura. Em sete dos 16 pacientes, concluímos que as mutações únicas nos genes GJB2 ou GJB6 provavelmente não estão relacionadas diretamente à causa de surdez, permanecendo sete casos com etiologia a esclarecer. 
Capítulo 4 


\section{CAPÍTULO 4}

Estabelecimento de culturas primárias de células neuro-epiteliais do órgão de Corti de cobaias e camundongos

\subsection{Introdução}

Diversas mutações que causam surdez em humanos já foram identificadas tanto em genes expressos nas células ciliadas ( $M Y O 7 A, K C N Q 4)$ quanto em genes expressos nas células de suporte (GJB2 e GJBO) do órgão de Corti (Van Camp e Smith, 2011).

Embora a função das células ciliadas sensoriais e de seus neurônios associados já estejam estabelecidas, as funções das células de suporte emergiram de estudos mais recentes. Diversos estudos têm demonstrado que essas células não sensoriais apresentam papel importante no desenvolvimento, na função e na manutenção da homeostasia da orelha interna (Cotanche e Kaiser, 2010, GomesCasati e col., 2010; Warchol e col., 2010). Além disso, as células de suporte parecem ser importantes reguladores da atividade sináptica no órgão de Corti (Stankovic e col., 2004; Sugawara e col., 2005; Glowatzki e col., 2006; Tritsch e col., 2007).

A expressão do inibidor do ciclo celular p2 $7^{\text {kip } 1}$ nas células de suporte do órgão de Corti maduro está relacionado com o seu estado de quiescência mitótica. Estudos com camundongos nocautes para o p27kip1 têm demonstrado que a sua deleção resulta na proliferação contínua das células de suporte do órgão de Corti (Chen e Segil,1999; Lowenheim e col., 1999, Ono e col., 2009). White e col., (2006), após dissociação e purificação das células de suporte de camundongos por FACS (Fluorescence-activated ㅌell sorting) verificaram que essas células são capazes de se proliferarem e de se transdiferenciarem em células ciliadas e que esse fenômeno é acompanhado pela redução da expressão do p27kip1. Esses estudos sugerem que há uma correlação entre os níveis de expressão do p27kip1 e a capacidade das células de suporte dos mamíferos de re-entrarem no ciclo celular, e que embora as células de suporte dos mamíferos apresentem in vitro potencial de regeneração semelhante ao observado em aves, esse potencial deve ser suprimido quando no interior tecido. 
As células menos diferenciadas encontradas na cóclea dos mamíferos são progenitoras das células ciliadas e das de suporte. No órgão de Corti, as células com características de progenitoras localizam-se em regiões onde residem as células de suporte mais próximas às células ciliadas, como por exemplo, as células Deiters vizinhas das células ciliadas externas e as inner phalengeals junto às células ciliadas internas (Figura 1.3, pág. 13, Capítulo 1) (Smeti e col., 2010). Com base nos ensaios para o isolamento de células-tronco do sistema nervoso central de mamíferos (Reynolds e Rieze, 2005), em diversos estudos foi possível purificar e isolar uma população de células progenitoras na cóclea de camundongos recém-nascidos (Malgrange e col., 2002; Li e col., 2003; Oshima e col., 2007; Savary e col., 2007; Senn e col., 2007). Essas células, quando mantidas em condições de cultivo não aderentes, são capazes de formar colônias de células flutuantes, denominadas "otoesferas". As células das otoesferas, quando dissociadas, são capazes de formar novas esferas, ou seja, são capazes de se auto-renovar, expressam marcadores que são produtos de genes importantes para o desenvolvimento tanto da orelha interna (ex.: Pax2, BMP-4, BMP-7) quanto do sistema nervoso (ex.: nestina) e podem se diferenciar nos seguintes tipos celulares: células que expressam marcadores de células de suporte (ex.: p27kip1, Jagged 1) ou marcadores de células ciliadas do órgão de Corti (Miosina VIIa, Jagged 2) (Li e col., 2003; Oshima e col., 2007; Savary e col., 2007; Senn e col., 2007). No entanto, os fatores moleculares responsáveis pela promoção da auto-renovação e da formação dessas esferas celulares ainda não foram completamente caracterizados (Doetzlhofer e col., 2004; Zhai e col., 2005; White e col., 2006; Savary e col., 2008).

Em virtude da irreversibilidade da maior parte dos casos de surdez, pesquisas recentes buscam desvendar os mecanismos moleculares e celulares relacionados à fisiologia da audição e, consequentemente, à sua perda, por meio de diversas estratégias. Modelos animais, culturas de células e estudos funcionais sobre mutações que causam surdez têm auxiliado a revelar o papel de várias moléculas na fisiologia da audição. Dado que as proteínas conexinas 26 e 30 se co-localizam nas células de suporte do órgão de Corti, onde possuem papel importante em vários processos de transdução auditiva, o cultivo de células epiteliais do órgão de Corti em 
laboratório e o estudo da sua diferenciação in vitro representam passo fundamental para estudos básicos de identificação e localização de proteínas relacionadas à função auditiva.

\subsection{Objetivo}

Padronizar protocolos para cultivo e diferenciação in vitro de células epiteliais do órgão de Corti, para criarmos, a médio prazo, condições experimentais fundamentais para estudos relacionados ao papel das conexinas e suas "parceiras" na audição e, a longo prazo, para o desenvolvimento de estratégias de terapia celular e gênica na deficiência auditiva.

\subsection{Animais e Métodos}

\subsubsection{Animais \\ Cobaias (Cavia porcellus)}

As cobaias foram fornecidas pelo CEDEME - UNIFESP (Centro de Desenvolvimento de Modelos Experimentais para Medicina e Biologia da Universidade Federal de São Paulo, São Paulo, Brasil), que foi responsável pela sua manutenção e manejo. O protocolo para trabalho com esses animais foi submetido à Comissão de Ética para Análise de Projetos de Pesquisa - CAPPesq da Diretoria Clínica do Hospital das Clínicas e da Faculdade de Medicina da Universidade de São Paulo e aprovado (Protocolo de pesquisa No 1221/06).

$\mathrm{Na}$ fase de pré-experimento, os animais foram mantidos em gaiolas grandes de polipropileno, com maravalha esterilizada no forro do piso, ração específica e água acrescida de vitamina C (20 gotas - $200 \mathrm{mg} /$ litro), renovadas diariamente. Os animais foram transportados em gaiolas do biotério ao Instituto de Biociências da USP, onde foram realizados os experimentos. Foram utilizados somente animais recém-nascidos (3 - 4 dias), machos e/ou fêmeas, saudáveis, pesando entre 100 300 gramas. Os animais foram tratados de acordo com os princípios éticos e 
diferenciação observados nas culturas do órgão de Corti de cobaias são também evidências da maturação precoce da cóclea nessas espécies quando comparada a dos camundongos.

\subsection{Conclusão}

Durante o período referente ao doutorado, conseguimos padronizar o cultivo de células dissociadas do órgão de Corti de cobaias e camundongos, caracterizar as células presentes nas otoesferas formadas nessas culturas por imunofluorescência indireta e avaliar o seu potencial de renovação e de diferenciação em células ciliadas e de suporte, atingindo o nosso objetivo. Nossos resultados indicam que o enriquecimento do meio de cultura com os fatores de crescimento EGF e TGF $\alpha$ é uma boa alternativa para obtenção de maior número otoesferas. A espécie Mus musculus se mostrou ser a mais adequada ao estabelecimento de culturas em suspensão de otoesferas quando analisadas entre P2 e P3.

Em experimentos futuros, pretendemos selecionar as células de suporte obtidas após diferenciação e avaliarmos sua capacidade de cultivo in vitro, para futuramente podermos utilizar essas células em nossos estudos sobre proteínas parceiras da conexina 26. 
Capítulo 5 


\section{CAPÍTULO 5}

Pesquisa e identificação de proteínas que interagem com a Cx26

\subsection{Introdução}

Regiões de interação entre células ou entre célula e substrato são especializações da membrana plasmática formadas por complexos protéicos que se associam à membrana plasmática, às moléculas do citoesqueleto e da matriz extracelular. Tais complexos incluem as junções ocludentes (tight junction), as junções de ancoramento (junções aderentes, desmossomas e hemidesmossomas) e as junções do tipo fenda (Duffy e col., 2002).

Nos vertebrados, as conexinas são as proteínas estruturais constituintes dos canais de junção do tipo fenda. No desenvolvimento, crescimento e diferenciação celular, esses canais e desempenham importante função na regulação da homeostasia tecidual, por meio da manutenção do pH e de concentrações iônicas. Além disso, promovem rápido transporte de pequenas moléculas entre células respondendo pelo fluxo direto de moléculas com massa molecular inferior a 2000 dáltons, como íons $\left(\mathrm{K}^{+}, \mathrm{Cl}^{-}\right.$), mensageiros secundários (IP3, AMPc e $\mathrm{Ca}^{+2}$ ), nucleotídeos (ADP, ATP e CTP), compostos do metabolismo intermediário (aminoácidos) e RNAs curtos. Os canais de junções do tipo fenda estão localizados em pontos específicos da membrana plasmática de duas células adjacentes formando estruturas altamente organizadas denominadas placas juncionais (Alberts e col., 2007, Dbouk e col., 2009). Nesses locais, tem-se demonstrado que as conexinas interagem com diversos outros componentes celulares que incluem elementos do citoesqueleto, enzimas (cinases e fosfatases), moléculas de adesão e moléculas sinalizadoras (Duffy e col., 2002; Hervé e col., 2007; Derangeon e col., 2008; Dbouk e col., 2009; Dror e Avraham, 2009; Laird e col., 2009).

$\mathrm{Na}$ região apical das células polarizadas, tem se observado frequentemente que as placas juncionais do tipo fenda mostram co-localização em relação às placas juncionais ocludentes, formando um complexo juncional. Vários estudos mostraram interação entre as conexinas e as proteínas das zônulas ocludentes ZO-1, ZO-2 e 
ZO-3 (sinônimo atualmente das Tight Junction Protein: TJP1, TJP2 e TJP3, respectivamente) (Hervé e col., 2004; Hervé e col., 2007; Derangeon e col., 2008; Dbouk e col., 2009; Dror e Avraham, 2009; Laird e col., 2009). As proteínas ZO das junções ocludentes de células epiteliais e endoteliais apresentam vários domínios PDZ (densidade pós-sináptica 95, grandes discos, zônula-ocludentes-1), responsáveis por ancorar proteínas integrantes de membrana às do citoesqueleto, que apresentam o motivo de ligação a PDZ ou PDZbm (Hervé e col., 2004; Brône e Eggermont, 2005). Esses estudos sugeriram que essas interações entre as proteínas $\mathrm{ZO}$ e as conexinas podem ter um papel regulatório na organização das placas de junções do tipo fenda (Kausalya e col., 2001; Hervé e col., 2004; Laird, 2005). O motivo PDZbm já foi funcionalmente demonstrado na região C-terminal das conexinas Cx30, Cx31.9, Cx32, Cx36, Cx40, Cx43, Cx45, Cx46, Cx47 e Cx50 (Tabela 5.1.). Interações entre domínios PDZ e PDZbm são um modelo recorrente para explicar o ancoramento de proteínas integrantes da membrana plasmática. Observa-se pela tabela 5.1. que, apesar da divergência em geral dos últimos dez resíduos C-terminais dessas conexinas, há algumas posições conservadas, como a última em que se observa serina $(\mathrm{S})$, isoleucina $(\mathrm{I})$, cisteína $(\mathrm{C})$ ou valina $(\mathrm{V})$ e três resíduos anteriores a última com a presença de serina $(\mathrm{S})$, aspartato $(\mathrm{D})$, cisteína $(\mathrm{C})$ ou treonina $(\mathrm{T})$ (marcados com asterisco).

Por outro lado, são poucas as proteínas conhecidas por interagirem física e funcionalmente com a Cx26. Em linhagem celular do intestino humano, foi descrita interação entre a Cx26 e um domínio específico da ocludina, que por sua vez interage com o domínio PDZ da ZO-1 (Nusrat e col., 2000). São conhecidas as proteínas OCP1/Fbox2 e OCP2/Skip1 que parecem relacionar-se à degradação da Cx26 e a consortina, proteína relacionada com o trânsito das Cx26 e Cx30 do complexo de Golgi à membrana plasmática (Nusrat e col., 2000; Nelson e col., 2007; Del Castillo e col., 2010).

A identificação de novas proteínas que interagem com a Cx26 pode ampliar o conhecimento funcional sobre as conexinas, indicar novos genes candidatos à surdez sindrômica e não-sindrômica, além de poder explicar os casos de surdez decorrentes de mutação isolada no gene GJB2. Estes casos poderiam ser atribuídos à 
herança digênica, ou seja, interação gênica entre o lócus da Cx26 e outros codificadores de proteínas distintas, porém associadas física e funcionalmente a ela. Alterações na sequência de aminoácidos ou nos níveis de expressão dessas proteínas poderiam perturbar sua interação com a Cx26 e levar à disfunção coclear e perda auditiva. Se essas alterações forem determinadas por alterações nos genes que codificam essas proteínas, novos genes e novas mutações potencialmente causadoras de surdez poderão ser identificados.

Tabela 5.1. Relação das conexinas descritas por interagir com os domínios PDZs das proteínas ZO-1 e a sequência dos últimos dez resíduos da região C-terminal de cada para a espécie (Mus musculus).

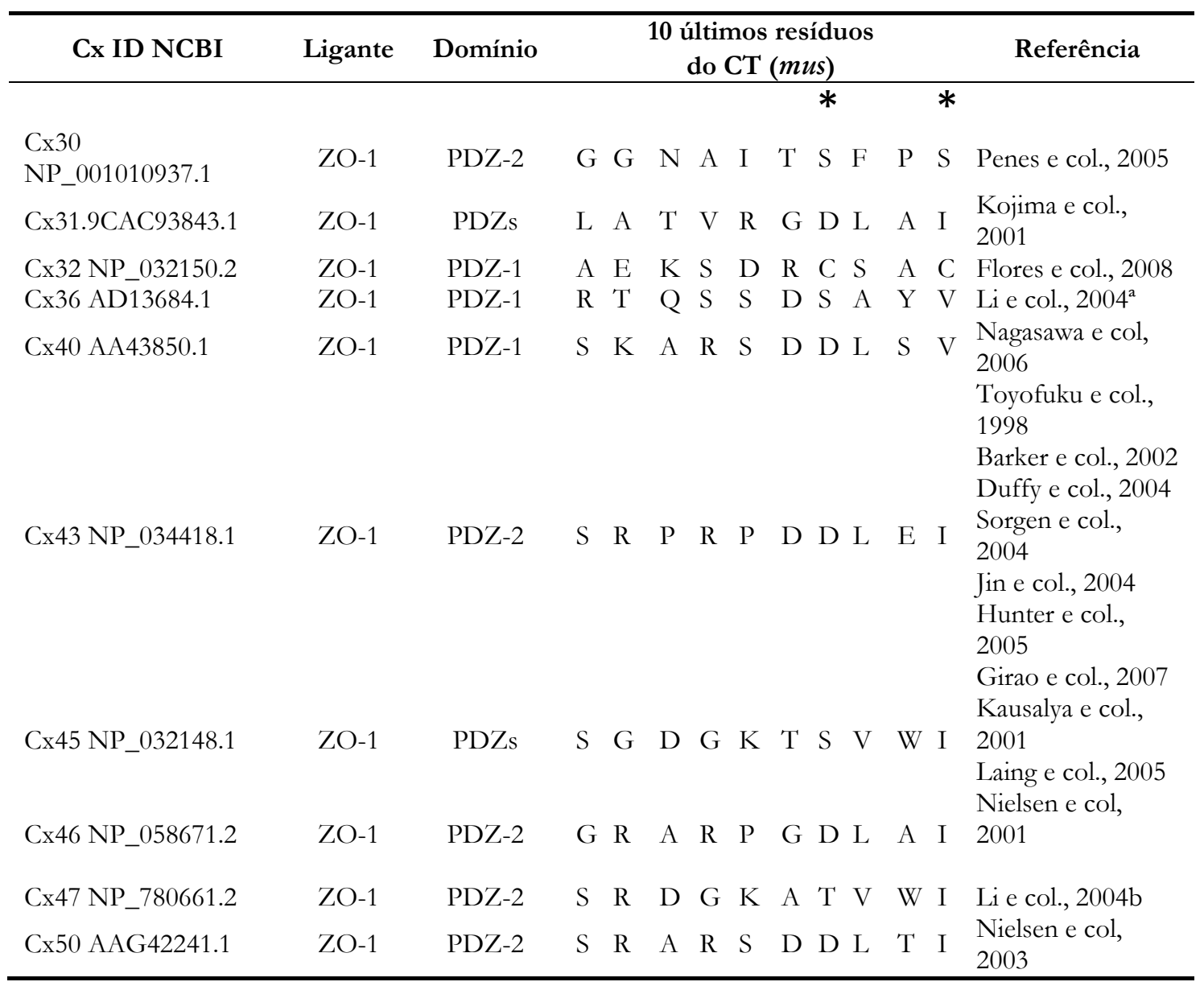

\subsection{Objetivo}

O objetivo desta etapa do trabalho foi identificar proteínas que interagem com a Cx26 e, desta forma, procurar compreender melhor as vias funcionais que atuam nessas células. Esses estudos podem culminar com a descoberta de novos genes candidatos para surdez, que possam interagir com o gene GJB2. Pretendemos 
meio de interferência por RNA. Os processos biológicos que se mostraram mais interessantes tendo em vista nossos objetivos são o transporte da Cx26 à membrana plasmática pela via secretora, a regulação da sua distribuição subcelular, a manutenção das junções do tipo fenda e o controle de sua atividade a partir da sinalização inter e intracelular.

\subsection{Conclusões}

Por meio do ensaio de precipitação por afinidade com a proteína de fusão GST-Cx26 e análise por espectrometria de massas das proteínas presentes em bandas de SDS-PAGE, obtidas no ensaio com a GST-Cx26 e ausentes no ensaio com a GST, identificamos um total de 49 proteínas candidatas a interagirem com a região C-terminal da Cx26.

Dessas 49 proteínas, dezesseis foram excluídas por redundância de representação no ensaio GST-Cx26 ou por diferença entre a massa molecular esperada e a observada. Seis proteínas foram excluídas por precipitação inespecífica. Das 27 proteínas restantes, após análises in silico em diferentes bancos de dados, quatro foram exlcuídas por localização subcelular incompatível com a Cx26 e uma protéina foi excluída por ter sido identificada por similaridade do peptídio à ubiquitina, sugerindo se tratar de alguma proteína ubiquitinada.

Vinte duas proteínas candidatas em potencial a interagir com a Cx26 foram analisadas e classificadas de acordo com a ferramenta de ontologia gênica, definindo a priori quatro grupos funcionais e um quinto grupo misto. Análises da literatura científica reagruparam essas 22 proteínas em três classes principais: proteínas responsáveis pela manutenção e ancoramento de proteínas integrantes da membrana plasmática ao citoesqueleto; proteínas envolvidas no transporte vesicular de moléculas na via secretora; e proteínas envolvidas na sinalização celular.

Dezenove das 22 proteínas são produtos de genes, cujos transcritos já foram demonstrados na orelha interna. A confimação da interação entre essas 22 proteínas 
e a conexina 26, será realizada em experimentos futuros por meio de estudos de colocalização e imuno-coprecipitação. 


\section{REFERÊNCIAS BIBLIOGRÁFICAS}




\section{REFERÊNCIAS BIBLIOGRÁFICAS}

Abe S, Usami S, Shinkawa H, Kelley PM, Kimberling WJ. Prevalent connexin 26 gene (GJB2) mutations in Japanese. J Med Genet. 2000;37:41-43.

Abreu-Silva RS, Lezirovitz K, Braga MC, Spinelli M, Pirana S, Della-Rosa VA, Otto PA, Mingroni-Netto RC. Prevalence of the A1555G (12S rRNA) and tRNA Ser(UCN) mitochondrial mutations in hearing-impaired Brazilian patients. Braz J Med Biol Res 2006; 39(2):219-26.

Acin-Perez R, Russwurm M, Günnewig K, Gertz M, Zoidl G, Ramos L, Buck J, Levin LR, Rassow J, Manfredi G, Steegborn C. A phosphodiesterase 2A isoform localized to mitochondria regulates respiration. J Biol Chem. 2011 [Epub ahead of print]

Ahmad J, Khan SN, Khan SY, Ramzan K, Riazuddin S, Ahmed ZM, Wilcox ER, Friedman TB, Riazuddin S. DFNB48, a new nonsyndromic recessive deafness locus, maps to chromosome 15q23-q25.1. Hum Genet 2005; 116(5): 407-12.

Ahn KS, Jeon SJ, Jung JY, Kim YS, Kang JH, Shin S, Choi T, Choi SJ, Chung P, Shim H. Isolation of embryonic stem cells from enhanced green fluorescent protein-transgenic mouse and their survival in the cochlea after allotransplantation. Cytotherapy. 2008;10(7):759-69.

Aijaz S, D'Atri F, Citi S, Balda MS, Matter K. Binding of GEF-H1 to the tight junctionassociated adaptor cingulin results in inhibition of Rho signaling and G1/S phase transition.Dev Cell. 2005 May;8(5):777-86.

Alberts B, Johnson A, Lewis J, Raff M, Roberts K, Walter P. Molecular Biology of the Cell. 5a Ed. Garland Science, New York, 2007.

Aller E, Jaijo T, García-García G, Aparisi MJ, Blesa D, Díaz-Llopis M, Ayuso C, Millán JM. Identification of large rearrangements of the PCDH15 gene by combined MLPA and a CGH: large duplications are responsible for Usher syndrome. Invest Ophthalmol Vis Sci. 2010 Nov;51(11):5480-5.

Altevogt BM, Paul DL. Four classes of intercellular channels between glial cells in the CNS. J Neurosci. 2004; 24(18): 4313-23.

Atar O, Avraham KB. Therapeutics of hearing loss: expectations vs reality. Drug Discov Today 2005;10(19):1323-30.

Barker RJ, Price RL, Gourdie RG. Increased association of ZO-1 with connexin43 during remodeling of cardiac gap junctions. Circ Res 2002; 90(3): 317-24.

Batissoco AC. Mutações nos genes GJB2 e GJB6 em Indivíduos com Deficiência Auditiva. Dissertação de Mestrado. Instituto de Biociências da USP. São Paulo, SP. (2006).

Baumgartner B, Harper JW. Deafening cycle. Nat Cell Biol 2003;5(5):385-7.

Beardslee MA, Laing JG, Beyer EC, Saffitz JE. Rapid turnover of connexin43 in the adult rat heart. Circ Res. 1998 Sep 21;83(6):629-35. 
Beltramello M, Piazza V, Bukauskas FF, Pozzan T, Mammano F.Impaired permeability to Ins $(1,4,5) \mathrm{P} 3$ in a mutant connexin underlies recessive hereditary deafness. Nat Cell Biol. 2005 Jan; 7(1):63-9.

Bernardini L, Palka C, Ceccarini C, Capalbo A, Bottillo I, Mingarelli R, Novelli A, Dallapiccola BComplex rearrangement of chromosomes 7q21.13-q22.1 confirms the ectrodactylydeafness locus and suggests new candidate genes. Am J Med Genet A. 2008 Jan $15 ; 146 \mathrm{~A}(2): 238-44$.

Bernardini L, Sinibaldi L, Capalbo A, Bottillo I, Mancuso B, Torres B, Novelli A, Digilio MC, Dallapiccola B. HDR (Hypoparathyroidism, Deafness, Renal dysplasia) syndrome associated to GATA3 gene duplication. Clin Genet. 2009 Jul;76(1):117-9.

Berthoud VM, Minogue PJ, Laing JG, Beyer EC. Pathways for degradation of connexins and gap junctions. Cardiovasc Res. 2004 May 1;62(2):256-67. Review.

Braga MCC, Otto PA, Spinelli M. Recurrence risks in cases of non-syndromic deafness. Braz J Dysmorph Speech Hearing Dis. 1999. 2:33-40.

Brigande JV, Heller S. Quo vadis, hair cell regeneration? Nat Neurosci. 2009 Jun;12(6):679-85. Review.

Brobby et al 1998 Connexin 26 R143W mutation associated with recessive non-syndromic sensorineural deafness in Africa. N Engl J Med 1998, 338:8, 548-50

Brône B, Eggermont J. PDZ proteins retain and regulate membrane transporters in polarized epithelial cell membranes. Am J Physiol Cell Physiol 2005; 288(1): C20-9.

Brownstein Z, Avraham KB. Future Trends and Potential for Treatment of Sensorineural Hearing Loss. Seminars in hearing. 2006; 27(3).

Bruzzone R, Veronesi V, Gomès D, Bicego M, Duval N, Marlin S, Petit C, D'Andrea P, White TW. Loss-of-function and residual channel activity of connexin 26 mutations associated with non-syndromic deafness. FEBS Lett. 2003 Jan 2;533(1-3):79-88.

Bruzzone R, White TW, Paul DL. Connections with connexins: the molecular basis of direct intercellular signaling. Eur J Biochem. 1996 May 15;238(1):1-27. Review.

Bulinski JC, Odde DJ, Howell BJ, Salmon TD, Waterman-Storer CM. Rapid dynamics of the microtubule binding of ensconsin in vivo. J Cell Sci 2001; 114(21): 3885-97.

Cama E, Melchionda S, Palladino T, Carella M, Santarelli R, Genovese E, Benettazzo F, Zelante L, Arslan E. Hearing loss features in GJB2 biallelic mutations and GJB2/GJB6 digenic inheritance in a large Italian cohort. Int J Audiol. 2009 Jan;48(1):12-7.

Cascio M. Connexins and their environment: effects of lipids composition on ion channels. Bioch and Biophy Acta 2005;1711:142-153.

Chen E, Obolensky E, Rauen KA, Shaffer LG, Li X. Cytogenetic and array CGH characterization of de novo $1 \mathrm{p} 36$ duplications and deletion in a patient with congenital cataracts, hearing loss, choanal atresia, and mental retardation. Am J Med Genet A. 2008 Nov 1;146A(21):2785-90. 
Chen P, Segil N. p27(Kip1) links cell proliferation to morphogenesis in the developing organ of Corti. Development. 1999 Apr;126(8):1581-90.

Chen P, Zindy F, Abdala C, Liu F, Li X, Roussel MF, et al. Progressive hearing loss in mice lacking the cyclin-dependent kinase inhibitor Ink4d. Nat Cell Biol 2003;5(5):422-6

Chen ZY. Applications of genomics in the inner ear. Pharmacogenomics 2003;4(6):735-45.

Chen ZY. Cell cycle, differentiation and regeneration: where to begin? Cell Cycle 2006;5(22):2609-12.

Chowdhury S, Shepherd JD, Okuno H, Lyford G, Petralia RS, Plath N, Kuhl D, Huganir RL, Worley PF. Arc/Arg3.1 interacts with the endocytotic machinery to regulate AMPA receptor trafficking. Neuron 2006; 52: 445-459.

Cohen-Salmon M, Ott T, Michel V, Hardelin JP, Perfettini I, Eybalin M, Wu T, Marcus DC, Wangemann P, Willecke K, Petit C. Targeted ablation of connexin26 in the inner ear epithelial gap junction network causes hearing impairment and cell death. Curr Biol. 2002 Jul 9;12(13):1106-11.

Common JE, Bitner-Glindzicz M, O'Toole EA, Barnes MR, Jenkins L, Forge A, Kelsell DP. Specific loss of connexin 26 expression in ductal sweat gland epithelium associated with the deletion mutation del(GJB6-D13S1830). Clin Exp dermatol. 2005 Nov;30(6):688-93.

Corda D, Colanzi A, Luini A.The multiple activities of CtBP/BARS proteins: the Golgi view. Trends Cell Biol. 2006 Mar;16(3):167-73. Epub 2006 Feb 17. Review.

Cordenonsi M, D'Atri F, Hammar E, Parry DA, Kendrick-Jones J, Shore D, Citi S. Cingulin contains globular and coiled-coil domains and interacts with ZO-1, ZO-2, ZO-3, and myosin. J Cell Biol 1999; 147(7): 1569-82.

Corwin JT, Cotanche DA. Regeneration of sensory hair cells after acoustic trauma. Science.1988;240:1772-1774.

Cotanche DA, Kaiser CL.Hair cell fate decisions in cochlear development and regeneration. Hear Res. 2010 Jul;266(1-2):18-25.

Cottrell GT, Burt JM. Functional consequences of heterogeneous gap junction channel formation and its influence in health and disease. Biochim Biophys Acta. 2005 Jun 10;1711(2):126-41. Review.

D'Atri F, Citi S. Cingulin interacts with F-actin in vitro. FEBS Lett 2001; 507(1): 21-4.

Dbouk HA, Mroue RM, El-Sabban ME, Talhouk RS. Connexins: a myriad of functions extending beyond assembly of gap junction channels. Cell Commun Signal 2009; 12:7-4.

de Kok YJ, Merkx GF, van der Maarel SM, Huber I, Malcolm S, Ropers HH, Cremers FP. A duplication/paracentric inversion associated with familial X-linked deafness (DFN3) suggests the presence of a regulatory element more than $400 \mathrm{~kb}$ upstream of the POU3F4 gene. Hum Mol Genet. 1995 Nov;4(11):2145-50.

del Castillo F, Aguirre L, Rodriguez-Ballesteros M, Villamar M, Moreno-Pelayo M, Moreno F, del Castillo I. A novel 200-kb deletion not involving the GBB6 (Connexin-30) gene at the DFNB1 locus is found in the compound heterozygous state with a GJB2 (Connexin-26) mutation in subjects with autosomal recessive hearing impairment. 7th Molecular Biology of Hearing and Deafness. Livro de resumos:85. 2009. 
del Castillo FJ, Cohen-Salmon M, Charollais A, Caille D, Lampe PD, Chavrier P, Meda P, Petit C. Consortin, a trans-Golgi network cargo receptor for the plasma membrane targeting and recycling of connexins. Hum Mol Genet 2010; 19(2): 262-75.

del Castillo FJ, Gandía M, Pollak A, Hoefsloot L, Silva-Costa SM, Batissoco A, Sartorato EL, Mingroni-Netto RC, Lechowicz L, Mueller-Malesinska M, Skarzynski H, Piotr H. Skarzynsk PS, Moreno-Pelayo MA, Villamar M, Moreno F, Kremer H, Ploski R, del Castillo I. A Multiplex Ligation-dependent Probe Amplification (MLPA) assay specifically developed to detect novel deletions causing nonsyndromic hearing impairment at the DFNB1 locus. In: 8th Molecular Biology of Hearing and Deafness Conference, 2011. Livro de resumos P51.

del Castillo FJ, Rodríguez-Ballesteros M, Alvarez A, Hutchin T, Leonardi E, de Oliveira CA, Azaiez H, Brownstein Z, Avenarius MR, Marlin S, Pandya A, Shahin H, Siemering KR, Weil D, Wuyts W, Aguirre LA, Martín Y, Moreno-Pelayo MA, Villamar M, Avraham KB, Dahl HH, Kanaan M, Nance WE, Petit C, Smith RJ, Van Camp G, Sartorato EL, Murgia A, Moreno F, del Castillo I. A novel deletion involving the connexin-30 gene, del(GJB6d13s1854), found in trans with mutations in the GJB2 gene (connexin-26) in subjects with DFNB1 non-syndromic hearing impairment. J Med Genet. 2005 Jul;42(7):588-94.

del Castillo I, Villamar M, Moreno-Pelayo MA, del Castillo FJ, Alvarez A, Tellería D, Menéndez I, Moreno F. A deletion involving the connexin 30 gene in nonsyndromic hearing impairment. N Engl J Med. 2002 Jan 24;346(4):243-9.

Delva E, Tucker DK, Kowalczyk AP. The Desmosome. Cold Spring Harb Perspect Biol 2009; 1:a002543.

Denoyelle F, Marlin S, Weil D, Moatti L, Chauvin P, Garabédian EN, Petit C. Clinical features of the prevalent form of childhood deafness, DFNB1, due to a connexin-26 gene defect: implications for genetic counselling. Lancet. 1999 Apr 17;353(9161):1298-303.

Denoyelle F, Weil D, Maw MA, Wilcox SA, Lench NJ, Allen-Powell DR, Osborn AH, Dahl HH, Middleton A, Houseman MJ, Dodé C, Marlin S, Boulila-ElGaïed A, Grati M, Ayadi H, BenArab S, Bitoun P, Lina-Granade G, Godet J, Mustapha M, Loiselet J, El-Zir E, Aubois A, Joannard A, Petit C, et al. Prelingual deafness: high prevalence of a 30delG mutation in the connexin 26 gene. Hum Mol Genet. 1997 Nov;6(12):2173-7.

Derangeon M, Bourmeyster N, Plaisance I, Pinet-Charvet C, Chen Q, Duthe F, Popoff MR, Sarrouilhe D, Hervé JC. RhoA GTPase and F-actin dynamically regulate the permeability of Cx43-made channels in rat cardiac myocytes. J Biol Chem 2008; 283(45): 30754-65.

Derangeon M, Spray DC, Bourmeyster N, Sarrouilhe D, Hervé JC. Reciprocal influence of connexins and apical junction proteins on their expressions and functions. Biochim Biophys Acta. 2009 Apr;1788(4):768-78. Epub 2008 Nov 11. Review.

Diensthuber M, Oshima K, Heller S.Stem/progenitor cells derived from the cochlear sensory epithelium give rise to spheres with distinct morphologies and features.J Assoc Res Otolaryngol. 2009 Jun;10(2):173-90.

Doetzlhofer A, White P, Lee YS, Groves A, Segil N. Prospective identification and purification of hair cell and supporting cell progenitors from the embryonic cochlea. Brain Res. 2006;1091:282-288. 
Doetzlhofer A, White PM, Johnson JE, Segil N, Groves AK. In vitro growth and differentiation of mammalian sensory hair cell progenitors: a requirement for EGF and periotic mesenchyme. Dev Biol 2004;272(2):432-47.

Dror AA, Avraham KB. Hearing loss: mechanisms revealed by genetics and cell biology. Annu Rev Genet 2009; 43:411-37.

Du QS, Ren XR, Xie Y, Wang Q, Mei L, Xiong WC. Inhibition of PYK2-induced actin cytoskeleton reorganization, PYK2 autophosphorylation and focal adhesion targeting by FAK. J Cell Sci. 2001 Aug;114(Pt 16):2977-87.

Duffy HS, Ashton AW, O'Donnell P, Coombs W, Taffet SM, Delmar M, Spray DC. Regulation of connexin43 protein complexes by intracellular acidification. Circ Res 2004; 94(2): 215-22.

Duffy HS, Delmar M, Spray DC. Formation of the gap junction nexus: binding partners for connexins. J Physiol Paris 2002; 96(3-4): 243-9.

Duncan LJ, Mangiardi DA, Matsui JI, Anderson JK, McLaughlin-Williamson K, Cotanche DA. Differential expression of unconventional myosins in apoptotic and regenerating chick hair cells confirms two regeneration mechanisms. J Comp Neurol. 2006 Dec 10;499(5):691-701.

Edge AS, Chen ZY. Hair cell regeneration. Curr Opin Neurobiol. 2008 Aug;18(4):377-82. Review.

Eisen MD, Ryugo DK. Hearing molecules: contributions from genetic deafness. Cell Mol Life Sci. 2007 Mar;64(5):566-80. Review.

Essenfelder GM, Larderet G, Waksman G, Lamartine J. Gene structure and promoter analysis of the human GJB6 gene encoding connexin 30. Gene. 2005 Apr 25;350(1):33-40.

Evans, WH. In J.B.C. Findlay and W.H. Evans (Eds.), Biological Membranes: A Practical Approach. IRL Press, Oxford, England, 1987, p. 1-25.

Fabre-Jonca N, Viard I, French LE, Masson D. Upregulation and redistribution of E-MAP 115 epithelial microtubule-associated protein of $115 \mathrm{kDa}$ ) terminally differentiating keratinocytes is coincident with the formation of intercellular contacts. J Invest Dermatol. 1999 Feb;112(2):216-25.

Falk MM, Buehler LK, Kumar Mn, Gilula NB. Cell-free synthesis and assembly of connexins into funcional gap junction membrane channels. EMBO J 1997;16:2703-2716.

Falk MM, Gilula NB. Connexin membrane protein biosynthesis is influenced by polypeptide positioning within the translocon and signal peptidades access. J Biol Chem 1998;273:78567864.

Fallon RF, Goodenough DA. Five-hour half-life of mouse liver gap-junction protein. J Cell Biol. 1981 Aug;90(2):521-6.

Fanning AS, Ma TY, Anderson JM. Isolation and functional characterization of the actin binding region in the tight junction protein ZO-1. FASEB J. 2002 Nov;16(13):1835-7.

Farazi TA, Waksman G, Gordon JI. The biology and enzymology of protein N-myristoylation. J Biol Chem 2001; 276(43): 39501-4. 
Feldmann D, Le Maréchal C, Jonard L, Thierry P, Czajka C, Couderc R, Ferec C, Denoyelle F, Marlin S, Fellmann F. A new large_deletion_in the DFNB1 locus causes nonsyndromic hearing loss. Eur J Med Genet. 2009 Jul-Aug;52(4):195-200.

Fjeld CC, Birdsong WT, Goodman RH. Differential binding of NAD+ and NADH allows the transcriptional corepressor carboxyl-terminal binding protein to serve as a metabolic sensor. Proc Natl Acad Sci USA 2003; 100(16): 9202-7.

Flam BR, Hartmann PJ, Harrell-Booth M, Solomonson LP, Eichler DC. Caveolar localization of arginine regeneration enzymes, argininosuccinate synthase, and lyase, with endothelial nitric oxide synthase.Nitric Oxide. 2001 Apr;5(2):187-97.

Flores CE, Li X, Bennett MV, Nagy JI, Pereda AE. Interaction between connexin35 and zonula occludens- 1 and its potential role in the regulation of electrical synapses. Proc Natl Acad Sci USA 2008; 105(34): 12545-50.

Forge A, Becker D, Casalotti S, Edwards J, Marziano N, Nevill G. Gap junctions in the inner ear: comparison of distribution patterns in different vertebrates and assessement of connexin composition in mammals. J Comp Neurol. 2003 Dec 8;467(2):207-31.

Forge A, Li L, Nevill G. Hair cell recovery in the vestibular sensory epithelia of mature guinea pigs. J Comp Neurol 1998;397(1):69-88.

Fujimoto K, Nagafuchi A, Tsukita S, Kuraoka A, Ohokuma A, Shibata Y. Dynamics of connexins, E-cadherin and alpha-catenin on cell membranes during gap junction formation. J Cell Sci. 1997 Feb;110 ( Pt 3):311-22.

Gasparini P, Rabionet R, Barbujani G, Melçhionda S, Petersen M, Brøndum-Nielsen K, Metspalu A, Oitmaa E, Pisano M, Fortina P, Zelante L, Estivill X. High carrier frequency of the 35delG deafness mutation in European populations. Genetic Analysis Consortium of GJB2 35delG. Eur J Hum Genet. 2000 Jan;8(1):19-23.

Gilleron J, Fiorini C, Carette D, Avondet C, Falk MM, Segretain D, Pointis G. Molecular reorganization of $\mathrm{Cx} 43, \mathrm{Zo}-1$ and Src complexes during the endocytosis of gap junction plaques in response to a non-genomic carcinogen. J Cell Sci. 2008 Dec 15;121(Pt 24):406978.

Girao H, Pereira P. J Cell Biochem. 2007 Oct 15;102(3):719-28. The proteasome regulates the interaction between Cx43 and ZO-1. J Cell Biochem 2007; 102(3): 719-28.

Glowatzki E, Cheng N, Hiel H, Yi E, Tanaka K, Ellis-Davies GC, Rothstein JD, Bergles DE The glutamate-aspartate transporter GLAST mediates glutamate uptake at inner hair cell afferent synapses in the mammalian cochlea. J Neurosci. 2006 Jul 19;26(29):7659-64.

Gómez-Casati ME, Murtie J, Taylor B, Corfas G.Cell-specific inducible gene recombination in postnatal inner ear supporting cells and glia. J Assoc Res Otolaryngol. 2010 Mar;11(1):19-26.

Groves AK. The challenge of hair cell regeneration. Exp Biol Med (Maywood). 2010 Apr;235(4):434-46. Review.

Grifa A, Wagner CA, D'Ambrosio L, Melchionda S, Bernardi F, Lopez-Bigas N, Rabionet R, Arbones M, Monica MD, Estivill X, Zelante L, Lang F, Gasparini P. Mutations in GJB6 cause nonsyndromic autosomal dominant deafness at DFNA3 locus. Nat Genet. 1999 Sep;23(1):16-8. 
Gu R, Montcouquiol M, Marchionni M, Corwin JT.Proliferative responses to growth factors decline rapidly during postnatal maturation of mammalian hair cell epithelia. Eur J Neurosci. 2007 Mar;25(5):1363-72.

Guillemot L, Citi S. Cingulin regulates claudin-2 expression and cell proliferation through the small GTPase RhoA. Mol Biol Cell 2006; 17(8): 3569-77.

Hammill, W. W., Fyfe, D. A., Gillette, P. C., Taylor, A., Dobson, R. L., Thompson, R. P. Cardiomyopathy with arrhythmias and ectodermal dysplasia: a previously unreported association. Am Heart J 1988; 115: 373-377.

Henzl MT, Thalmann I, Larson JD, Ignatova EG, Thalmann R. The cochlear F-box protein OCP1 associates with OCP2 and connexin 26. Hear Res. 2004 May;191(1-2):101-9.

Hernandez PP, Olivari FA, Sarrazin AF, Sandoval PC, Allende ML. Regeneration in zebrafish lateral line neuromasts: expression of the neural progenitor cell marker sox 2 and proliferation-dependent and-independent mechanisms of hair cell renewal. Dev Neurobiol.2007;67:637-654.

Hervé JC, Bourmeyster N, Sarrouilhe D. Diversity in protein-protein interactions of connexins: emerging roles. Biochim Biophys Acta. 2004 Mar 23;1662(1-2):22-41. Review.

Hervé JC, Derangeon M, Bahbouhi B, Mesnil M, Sarrouilhe D. The connexin turnover, an important modulating factor of the level of cell-to-cell junctional communication: comparison with other integral membrane proteins. J Memb Biol 2007; 217(1-3):21-33.

Hida Y, Ohtsuka T. CAST and ELKS proteins: structural and functional determinants of the presynaptic active zone. J Biochem 2010; 148(2): 131-137.

Hilgert N, Smith RJ, Van Camp G. Function and expression pattern of nonsyndromic deafness genes. Curr Mol Med. 2009 Jun;9(5):546-64. Review.

Holme, Ralph H., Bussoli, Tracy J. and Steel, Karen P. Table of gene expression in the developing ear. World Wide Web URL: http://www.ihr.mrc.ac.uk/legacy/hereditary/ genetable/index.html

Huang X, Shi Z, Wang W, Bai J, Chen Z, Xu J, Zhang D, Fu S. Identification and characterization of a novel protein ISOC2 that interacts with p16INK4a. Biochem Biophys Res Comm 2007; 361: 287-293.

Hume CR, Bratt DL, Oesterle EC. Expression of LHX3 and SOX2 during mouse inner ear development. Gene Expr Patterns. 2007;7:798-807.

Hunter AW, Barker RJ, Zhu C, Gourdie RG. Zonula occludens-1 alters connexin43 gap junction size and organization by influencing channel accretion. Mol Biol Cell 2005; 16(12): 5686-98.

Jeronimo C, Forget D, Bouchard A, Li Q, Chua G, Poitras C, Thérien C, Bergeron D, Bourassa S, Greenblatt J, Chabot B, Poirier GG, Hughes TR, Blanchette M, Price DH, Coulombe B.Systematic analysis of the protein interaction network for the human transcription machinery reveals the identity of the 7SK capping enzyme. Mol Cell. $2007 \mathrm{Jul}$ 20;27(2):262-74. 
Jin C, Martyn KD, Kurata WE, Warn-Cramer BJ, Lau AF. Connexin43 PDZ2 binding domain mutants create functional gap junctions and exhibit altered phosphorylation. Cell Commun Adhes 2004; 11(2-4): 67-87.

Jones JM, Montcouquiol M, Dabdoub A, Woods C, Kelley MW. Inhibitors of differentiation and DNA binding (Ids) regulate Math1 and hair cell formation during the development of the organ of Corti. J Neurosci 2006;26(2):550-8.

Junqueira LC; Carneiro J. Histologia Básica. $9^{\circ}$ edição - Editora Guanabara Koogan S.A., Rio de Janeiro. 1999.

Kaplan SR, Gard JJ, Protonotarios N, Tsatsopoulou A, Spiliopoulou C, Anastasakis A, Squarcioni CP, McKenna WJ, Thiene G, Basso C, Brousse N, Fontaine G, Saffitz JE. Remodeling of myocyte gap junctions in arrhythmogenic right ventricular cardiomyopathy due to a deletion in plakoglobin (Naxos disease). Heart Rhythm 2004; 1(1): 3-11.

Kausalya PJ, Reichert M, Hunziker W. Connexin45 directly binds to ZO-1 and localizes to the tight junction region in epithelial MDCK cells. FEBS Lett 2001; 505(1): 92-6.

Kawamoto K, Yagi M, Stöver T, Kanzaki S, Raphael Y.Hearing and hair cells are protected by adenoviral gene therapy with TGF-beta1 and GDNF. Mol Ther. 2003 Apr;7(4):484-92.

Kazuya Ono , Takayuki Nakagawa, Ken Kojima, Masahiro Matsumoto, Takeshi Kawauchi, Mikio Hoshino, Juichi Ito. Silencing p27 reverses post-mitotic state of supporting cells in neonatal mouse cochleae. Molecular and Cellular Neuroscience 42 (2009) 391-398

Keats BJ, Berlin CI. Genomics and hearing impairment. Genome Res. 1999 Jan;9(1):7-16. Review.

Keller HU, Niggli V. Colchicine-induced stimulation of PMN motility related to cytoskeletal changes in actin, alpha-actinin, and myosin. Cell Motil Cytoskeleton 1993; 25(1): 10-8.

Kelley MW. Regulation of cell fate in the sensory epithelia of the inner ear. Nat Rev Neurosci. 2006;7(11):837-49.

Kelsell DP, Dunlop J, Stevens HP, Lench NJ, Liang JN, Parry G, Mueller RF, Leigh IM. Connexin 26 mutations in hereditary non-syndromic sensorineural deafness. Nature. 1997 May 1;387(6628):80-3.

Kenneson A, Van Naarden Braun K, Boyle C. GJB2 (connexin 26) variants and nonsyndromic sensorineural hearing loss: a HuGE review. Genet Med. 2002 Jul-Aug;4(4):258-74. Review.

Kiang DT, Jin N, Tu ZJ, Lin HH. Upstream genomic sequence of the human connexin26 gene. Gene. 1997 Oct 15;199(1-2):165-71.

Kieken F, Mutsaers N, Dolmatova E, Virgil K, Wit AL, Kellezi A, Hirst-Jensen BJ, Duffy HS, Sorgen PL. Structural and molecular mechanisms of gap junction remodeling in epicardial border zone myocytes following myocardial infarction. Circ Res. 2009 May 8;104(9):110312.

Ko J, Na M, Kim S, Lee JR, Kim E. Interaction of the ERC family of RIM-binding proteins with the liprin-alpha family of multidomain proteins. J Biol Chem. 2003 Oct 24;278(43):42377-85. Epub 2003 Aug 15. 
Kojima T,Kokai Y, Chiba H, Yamamoto, M. Mochizuki Y, Sawada N., Cx32 but not Cx26 is associated with tight junctions in primary cultures of rat hepatocytes, Exp. Cell Res. 263 (2001) 193-201

Konings A, Van Laer L, Van Camp G. Genetic studies on noise-induced hearing loss: a review. Ear Hear. 2009 Apr;30(2):151-9.

Kopke RD, Jackson RL, Li G, Rasmussen MD, Hoffer ME, Frenz DA, Costello M, Schultheiss P, Van De Water TR. Growth factor treatment enhances vestibular hair cell renewal and results in improved vestibular function. Proc Natl Acad Sci USA. 2001;98:5886-5891.

Koval M. Pathways and control of connexin oligomerization. Trends Cell Biol. 2006 Mar;16(3):159-66. Review.

Kriechbaumer V, von Löffelholz O, Abell BM. Chaperone receptors: guiding proteins to intracellular compartments. Protoplasma. $2011 \mathrm{Apr}$ 3. [Epub ahead of print] PMID:21461941

Krutovskikh V, Yamasaki H. Connexin gene mutations in human genetic diseases. Mutat Res. 2000 Apr;462(2-3):197-207. Review.

Kudo T, Kure S, Ikeda K, Xia AP, Katori Y, Suzuki M, Kojima K, Ichinohe A, Suzuki Y, Aoki Y, Kobayashi T, Matsubara Y Transgenic expression of a dominant-negative connexin26 causes degeneration of the organ of Corti and non-syndromic deafness. Hum Mol Genet. 2003 May 1;12(9):995-1004.

Kuntz AL, Oesterle EC. Transforming growth factor alpha with insulin stimulates cell proliferation in vivo in adult rat vestibular sensory epithelium. J Comp Neurol. 1998;399:413-423.

Laing JG, Beyer EC. The gap junction protein connexin43 is degraded via the ubiquitin proteasome pathway. J Biol Chem. 1995 Nov 3;270(44):26399-403.

Laing JG, Koval M, Steinberg TH. Association with ZO-1 correlates with plasma membrane partitioning in truncated connexin45 mutants. J Membr Biol 2005; 207(1): 45-53.

Laird DW, Puranam KL, Revel JP. Turnover and phosphorylation dynamics of connexin43 gap junction protein in cultured cardiac myocytes. Biochem J. 1991 Jan 1;273(Pt 1):67-72.

Laird DW. Connexin phosphorylation as a regulatory event linked to gap junction internalization and degradation. Biochim Biophys Acta. 2005 Jun 10;1711(2):172-82. Review.

Laird DW. Life cycle of connexins in health and disease. Biochem J. 2006 Mar 15;394(Pt 3):527-43. Review.

Laird DW. The gap junction proteome and its relationship to disease. Trends Cell Biol. 2010 Feb;20(2):92-101. Review.

Landlinger C, Salzer U, Prohaska R. Myristoylation of human LanC-like protein 2 (LANCL2) is essential for the interaction with the plasma membrane and theincrease in cellular sensitivity to adriamycin. Biochim Biophys Acta 2006; 1758(11):1759-67. 
Lanford PJ, Lan Y, Jiang R, Lindsell C, Weinmaster G, Gridley T, Kelley MW. Notch signalling pathway mediates hair cell development in mammalian cochlea. Nat Genet. 1999;21:289292.

Langer, L. O., Jr., Gorlin, R. J., Donnai, D., Hamel, B. C. J., Clericuzio, C. Spondylocarpotarsal synostosis syndrome (with or without unilateral unsegmented bar). Am J Med Genet 1994; 51: 1-8.

Lautermann J, Frank HG, Jahnke K, Traub O, Winterhager E. Developmental expression patterns of connexin26 and -30 in the rat cochlea. Dev Genet. 1999;25(4):306-11.

Lefebvre PP, Van De Water TR. Connexins, hearing and deafness: clinical aspects of mutations in the connexin 26 gene. Brain Res Brain Res Rev. 2000 Apr;32(1):159-62. Review.

Lehman AM, Friedman JM, Chai D, Zahir FR, Marra MA, Prisman L, Tsang E, Eydoux P, Armstrong L. A characteristic syndrome associated with microduplication of 8q12, inclusive of CHD7. Eur J Med Genet. 2009 Nov-Dec;52(6):436-9.

Lerer I, Sagi M, Malamud E, Levi H, Raas-Rothschild A, Abeliovich D. Contribution of connexin 26 mutations to nonsyndromic deafness in Ashkenazi patients and the variable phenotypic effect of the mutation 167delT. Am J Med Genet. 2000 Nov 6;95(1):53-6.

Leung CT, Coulombe PA, Reed RR. Contribution of olfactory neural stem cells to tissue maintenance and regeneration. Nat Neurosci. 2007 Jun;10(6):720-6.

Lezirovitz K, Batissoco AC, Lima FT, Auricchio MTBM, Dantas VGL, Oiticica J, MingroniNetto RC. Splice donor site deletion in the TECTA gene causing autosomal dominant deafness in a Brazilian family. In: 8th Molecular Biology of Hearing and Deafness Conference, 2011. Livro de resumos P15.

Li X, Olson C, Lu S, N. Kamasawa, T. Yasumura, J.E. Rash, J.I. Nagy, Neuronal connexin36 association with zonula occludens- 1 protein (ZO-1) in mouse brain and interaction with the first PDZ domain of ZO-1, Eur. J. Neurosci. 19 (2004c)2132-2146.

Li X, Ionescu AV, Lynn BD, Lu S, Kamasawa N, Morita N, Davidson KG, Yasumura T, Rash JE, Nagy JI, Connexin47, connexin29 and connexin32 coexpression in oligodendrocytes and $\mathrm{Cx} 47$ association with zonula occludens-1(ZO-1) in mouse brain, Neuroscience 126 (2004c) 611-630.

Li H, Corrales CE, Edge A, Heller S. Stem cells as therapy for hearing loss. Trends Mol Med.2004;10:309-315.

Li H, Liu H, Heller S. Pluripotent stem cells from the adult mouse inner ear. Nat Med 2003;9(10):1293-9 (b).

Li H, Roblin G, Liu H, Heller S. Generation of hair cells by stepwise differentiation of embryonic stem cells. Proc Natl Acad Sci USA. 2003;100(23):13495-500 (a).

Liu Q, Gao J, Chen X, Chen Y, Chen J, Wang S, Liu J, Liu X, Li J. HBP21: a novel member of tpr motif family, as a potential chaperone of heat shock protein 70 in proliferative vitreoretinopathy (PVR) and breast cancer. Mol Biotechnol 2008; 40: 231-40.

Liu W, Sato A, Khadka D, Bharti R, Diaz H, Runnels LW, Habas R. Mechanism of activation of the Formin protein Daam1. Proc Natl Acad Sci USA 2008; 105(1): 210-5. 
Liu XZ, Xia XJ, Xu LR, Pandya A, Liang CY, Blanton SH, Brown SD, Steel KP, Nance WE. Mutations in connexin31 underlie recessive as well as dominant non-syndromic hearing loss. Hum Mol Genet. 2000 Jan 1;9(1):63-7.

Locke D, Bian S, Li H, Harris AL. Post-translational modifications of connexin26 revealed by mass spectrometry. Biochem J. 2009 Dec 10;424(3):385-98.

Lopez IA, Zhao PM, Yamaguchi M, de Vellis J, Espinosa-Jeffrey A.Stem/progenitor cells in the postnatal inner ear of the GFP-nestin transgenic mouse. Int J Dev Neurosci. 2004 Jun;22(4):205-13

Lou X, Zhang Y, Yuan C. Multipotent stem cells from the young rat inner ear. Neurosci Lett 2007;416(1):28-33.

Löwenheim H, Furness DN, Kil J, Zinn C, Gültig K, Fero ML, Frost D, Gummer AW, Roberts JM, Rubel EW, Hackney CM, Zenner HP. Gene disruption of p27(Kip1) allows cell proliferation in the postnatal and adult organ of corti. Proc Natl Acad Sci USA. 1999 Mar 30;96(7):4084-8.

Löwenheim, H., Furness, D.N., Kil, J., Zinn, C., Gültig, K., Fero, M.L., Frost, D., Gummer, A.W., Roberts, J.M., Rubel, E.W., Hackney, C.M., Zenner, H.P., 1999. Gene disruption of p27(Kip1) allows cell proliferation in the postnatal and adult organ of Corti. Proc. Natl. Acad. Sci. U. S. A. 96, 4084-4088.

Lu J, Lian G, Lenkinski R, De Grand A, Vaid RR, Bryce T, Stasenko M, Boskey A, Walsh C, Sheen V. Filamin B mutations cause chondrocyte defects in skeletal development. Hum Mol Genet 2007; 16(14): 1661-75. (b)

Lu J, Meng W, Poy F, Maiti S, Goode BL, Eck MJ. Structure of the FH2 domain of Daam1: implications for formin regulation of actin assembly. J Mol Biol 2007; 369(5): 1258-69.(a)

Lundin J, Söderhäll C, Lundén L, Hammarsjö A, White I, Schoumans J, Läckgren G, Kockum CC, Nordenskjöld A. 22q11.2 microduplication in two patients with bladder exstrophy and hearing impairment. Eur J Med Genet. 2010 Mar-Apr;53(2):61-5.

Maeda S, Nakagawa S, Suga M, Yamashita E, Oshima A, Fujiyoshi Y, Tsukihara T. Structure of the connexin 26 gap junction channel at 3.5 A resolution. Nature 2009; 458(7238): 597-602.

Maestrini, E., Korge, B. P., Ocana-Sierra, J., Calzolari, E., Cambiaghi, S., Scudder, P. M., Hovnanian, A., Monaco, A. P., Munro, C. S. A missense mutation in connexin26, D66H, causes mutilating keratoderma with sensorineural deafness (Vohwinkel's syndrome) in three unrelated families. Hum Molec Genet 1999; 8: 1237-1243.

Martinez-Monedero R, Yi E, Oshima K, Glowatzki E, Edge AS. Differentiation of inner ear stem cells to functional sensory neurons. Dev Neurobiol. 2008;68:669-684.

Marziano NK, Casalotti SO, Portelli AE, Becker DL, Forge A. Mutations in the gene for connexin 26 (GJB2) that cause hearing loss have a dominant negative effect on connexin 30. Hum Mol Genet. 2003 Apr 15;12(8):805-12.

Masson D, Kreis TE. Identification and molecular characterization of E-MAP-115, a novel microtubule-associated protein predominantly expressed in epithelial cells. J Cell Biol 1993; 123(2): 357-71. 
Mathijssen IB, Hoovers JM, Mul AN, Man HY, Ket JL, Hennekam RC. Array comparative genomic hybridization analysis of a familial duplication of chromosome 13q: a recognizable syndrome. Am J Med Genet A. 2005 Jul 1;136(1):76-80.

Matos TD, Caria H, Simões-Teixeira H, Aasen T, Nickel R, Jagger DJ, O'Neill A, Kelsell DP, Fialho G. A novel hearing-loss-related mutation occurring in the GJB2 basal promoter. J Med Genet. 2007 Nov;44(11):721-5.

Mayer MP, Bukau B. Hsp70 chaperones: cellular functions and molecular mechanism. Cell Mol Life Sci 2005; 62(6): 670-84.

McNamee MG. Isolation and characterization of cell membranes. Biotechniques 1989; 7(5): 466-75.

Meusser B, Hirsch C, Jarosch E, Sommer T. ERAD: the long road to destruction. Nat Cell Biol. 2005 Aug;7(8):766-72. Review.

Mingroni Netto RC, Uehara DT, Freitas EL, Mazzeu JF, Auricchio MTBM, Tabith Jr A, Rosenberg C. A Duplication in a Patient with Nonsyndromic Deafness Reveals a Novel Candidate Gene for Deafness, DOCK4. In: 8th Molecular Biology of Hearing and Deafness Conference, 2011. Livro de resumos T113.

Mingroni-Netto RC, Lezirovitz K, Uehara DT, Batissoco AC. Novel GJB2 duplication identified in a patient with nonsyndromic recessive hearing loss by MLPA (Multiplex Ligation-dependent Probe Amplification). In: 8th Molecular Biology of Hearing and Deafness Conference, 2011. Livro de resumos P52.

Morris KA, Snir E, Pompeia C, Koroleva IV, Kachar B, Hayashizaki Y, Carninci P, Soares MB, Beisel KW. Differential expression of genes within the cochlea as defined by a custom mouse inner ear microarray. J Assoc Res Otolaryngol 2005; 6(1):75-89.

Nagasawa K, Chiba H, Fujita H, Kojima T, Saito T, Endo T, Sawada N. Possible involvement of gap junctions in the barrier function of tight junctions of brain and ling endothelial cells. J Cell Physiol 2006; 208(1): 123-32.

Nagy JI, Li X, Rempel J, Stelmack G, Patel D, Staines WA, Yasumura T, Rash JE. Connexin26 in adult rodent central nervous system: demonstration at astrocytic gap junctions and colocalization with connexin30 and connexin43. J Comp Neurol 2001; 441(4): 302-23.

Najmabadi H, Nishimura C, Kahrizi K, Riazalhosseini Y, Malekpour M, Daneshi A, Farhadi M, Mohseni M, Mahdieh N, Ebrahimi A, Bazazzadegan N, Naghavi A, Avenarius M,Arzhangi S, Smith RJ. GJB2 mutations: passage through Iran.Am J Med Genet A. 2005 $\operatorname{Mar} 1 ; 133 \mathrm{~A}(2): 132-7$.

Nakagawa T, Lomb DJ, Haigis MC, Guarente L.SIRT5 Deacetylates carbamoyl phosphate synthetase 1 and regulates the urea cycle. Cell. 2009; 137(3): 560-70.

Nelson HD, Bougatsos C, Nygren P; 2001 US Preventive Services Task Force. Universal newborn hearing screening: systematic review to update the 2001 US Preventive Services Task Force Recommendation. Pediatrics. 2008 Jul;122(1):e266-76. Review. Erratum in: Pediatrics. 2008 Sep;122(3):689.

Nelson RF, Glenn KA, Zhang Y, Wen H, Knutson T, Gouvion CM, Robinson BK, Zhou Z, Yang B, Smith RJ, Paulson HL. Selective cochlear degeneration in mice lacking the F-box protein, Fbx2, a glycoprotein-specific ubiquitin ligase subunit. J Neurosci. 2007 May 9;27(19):5163-71. 
Nielsen PA, Baruch A, Giepmans BN, Kumar NM. Characterization of the association of connexins and ZO-1 in the lens. Cell Commun Adhes 2001; 8(4-6): 213-7.

Nielsen PA, Baruch A, Shestopalov VI, Giepmans BN, Dunia I, Benedetti EL, Kumar NM. Lens connexins alpha3Cx46 and alpha8Cx50 interact with zonula occludens protein-1 (ZO1). Mol Biol Cell 2003; 14(6): 2470-81.

Nusrat A, Chen JA, Foley CS, Liang TW, Tom J, Cromwell M, Quan C, Mrsny RJ. The coiledcoil domain of occludin can act to organize structural and functional elements of the epithelial tight junction. J Biol Chem 2000; 275(38): 29816-22.

Oiticica J, Batissoco AC, Junior LCMB, Netto RCM, Haddad LA, Bento RF. Organ of Corti culture for functional analysis of precursor, support and hair cells. Arq Int Otorrinolaringol 2007;11(4):433-437.

Ono K, Nakagawa T, Kojima K, Matsumoto M, Kawauchi T, Hoshino M, Ito J. Silencing p27 reverses post-mitotic state of supporting cells in neonatal mouse cochleae. Mol Cell Neurosci. 2009 Dec;42(4):391-8.

Oshima K, Grimm CM, Corrales CE, Senn P, Martinez Monedero R, Geleoc GS, Edge A, Holt JR, Heller S. Differential distribution of stem cells in the auditory and vestibular organs of the inner ear. J Assoc Res Otolaryngol. 2007;8:18-31.

Pallares-Ruiz N, Blanchet P, Mondain M, Claustres M, Roux AF. A large deletion including most of GJB6 in recessive non syndromic deafness: a digenic effect? Eur J Hum Genet. 2002 Jan;10(1):72-6.

Parker MA, Cotanche DA. The potential use of stem cells for cochlear repair. Audiol Neurootol 2004;9(2):72-80.

Parker MA, Jiang K, Kempfle JS, Mizutari K, Simmons CL, Bieber R, Adams J, Edge AS.TAK1 Expression in the Cochlea: A Specific Marker for Adult Supporting Cells.J Assoc Res Otolaryngol. 2011 Aug;12(4):471-83.

Penes MC, Li X, Nagy JI. Expression of zonula occludens-1 (ZO-1) and the transcription factor ZO-1-associated nucleic acid-binding protein (ZONAB)-MsY3 in glial cells and colocalization at oligodendrocyte and astrocyte gap junctions in mouse brain. Eur J Neurosci 2005; 22(2): 404-18.

Peng YF, Mandai K, Sakisaka T, Okabe N, Yamamoto Y, Yokoyama S, Mizoguchi A, Shiozaki H, Monden M, Takai Y. Ankycorbin: a novel actin cytoskeleton-associated protein. Genes Cells 2000; 5(12): 1001-8.

Pfaffl MW. A new mathematical model for relative quantification in real-time RT-PCR.Nucleic Acids Res. 2001 May 1;29(9):e45.

Phillips-Mason PJ, Gates TJ, Major DL, Sacks DB, Brady-Kalnay SM. The receptor proteintyrosine phosphatase PTPmu interacts with IQGAP1. J Biol Chem. 2006 Feb 24:281(8):4903-10.

Piatto VB, Maniglia JV. Importância do gene Conexina 26 na etiologia da deficiência sensorioneural não sindrômica. Acta Awho. 2001. 20:106-112. 
Pranchevicius MC, Baqui MM, Ishikawa-Ankerhold HC, Lourenço EV, Leão RM, Banzi SR, dos Santos CT, Roque-Barreira MC, Espreafico EM, Larson RE.Myosin Va phosphorylated on Ser1650 is found in nuclear speckles and redistributes to nucleoli upon inhibition of transcription. Cell Motil Cytoskeleton. 2008 Jun;65(6):441-56.

Pujol R, Réclar-Enjalbert V, Pujol T. Promenade round the cochlea. World Wide Web URL:http://www.iurc.montp.inserm.fr/cric/audition/english/index.htm. Acesso em: Julho 2011

Pujol R. Morphology, synaptology and electrophysiology of the developing cochlea. Acta Otolaryngol Suppl. 1985;421:5-9.

Putcha GV, Bejjani BA, Bleoo S, Booker JK, Carey JC, Carson N, Das S, Dempsey MA, Gastier-Foster JM, Greinwald JH Jr, Hoffmann ML, Jeng LJ, Kenna MA, Khababa I,Lilley M, Mao R, Muralidharan K, Otani IM, Rehm HL, Schaefer F, Seltzer WK, Spector EB, Springer MA, Weck KE, Wenstrup RJ, Withrow S, Wu BL, Zariwala MA, Schrijver I. A multicenter study of the frequency and distribution of GJB2 and GJB6 mutations in a large North American cohort. Genet Med. 2007 Jul;9(7):413-26.

Rabionet R, Gasparini P, Estivill X. Molecular genetics of hearing impairment due to mutations in gap junction genes encoding beta connexins. Hum Mutat. 2000 Sep;16(3):190-202. Review.

Rackauskas M, Neverauskas V, Skeberdis VA. Diversity and properties of connexin gap junction channels. Medicina (Kaunas). 2010;46(1):1-12. Review.

Ramensky V, Bork P, Sunyaev S. Human non-synonymous SNPs: server and survey.Nucleic Acids Res. 2002 Sep 1;30(17):3894-900.

Ramsebner R, Volker R, Lucas T, Hamader G, Weipoltshammer K, Baumgartner WD, Wachtler FJ, Kirschhofer K, Frei K. High incidence of GJB2 mutations during screening of newborns for hearing loss in Austria. Ear Hear. 2007 Jun;28(3):298-301.

Ramsebner R, Volker R, Lucas T, Hamader G, Weipoltshammer K, Baumgartner WD, Wachtler FJ, Kirschhofer K, Frei K. High incidence of GJB2 mutations during screening of newborns for hearing loss in Austria. Ear Hear. 2007 Jun;28(3):298-301.

Raphael Y, Altschuler RA. Structure and innervation of the cochlea. Brain Res Bull 2003;60(56):397-422.

Rash JE, Yasumura T, Davidson KG, Furman CS, Dudek FE, Nagy JI. Identification of cells expressing Cx43, Cx30, Cx26, Cx32 and Cx36 in gap junctions of rat brain and spinal cord. Cell Commun Adhes. 2001;8(4-6):315-20.

Rask-Andersen H, Bostrom M, Gerdin B, Kinnefors A, Nyberg G, Engstrand T, Miller JM, Lindholm D. Regeneration of human auditory nerve. In vitro/in video demonstration of neural progenitor cells in adult human and guinea pig spiral ganglion. Hear Res. 2005;203:180-191.

Rask-Andersen H, Boström M, Gerdin B, Kinnefors A, Nyberg G, Engstrand T, Miller JM, Lindholm D. Ryals BM, Rubel EW. Hair cell regeneration after acoustic trauma in adult Coturnix quail.Science. 1988;240:1774-1776. 
Reynolds BA, Rietze RL.Neural stem cells and neurospheres--re-evaluating the relationship. Nat Methods. 2005 May;2(5):333-6.

Riazuddin S, Ahmed ZM, Fanning AS, Lagziel A, Kitajiri S, Ramzan K, Khan SN, Chattaraj P, Friedman PL, Anderson JM, Belyantseva IA, Forge A, Riazuddin S, Friedman TB.Tricellulin is a tight-junction protein necessary for hearing. Am J Hum Genet. 2006 Dec;79(6):1040-51. Epub 2006 Oct 31.

Richard G, Brown N, Ishida-Yamamoto A, Krol A. Expanding the phenotypic spectrum of Cx26 disorders: Bart-Pumphrey syndrome is caused by a novel missense mutation in GJB2.J Invest Dermatol 2004; 123(5): 856-63.

Richard G, White TW, Smith LE, Bailey RA, Compton JG, Paul DL, Bale SJ. Functional defects of $\mathrm{C} x 26$ resulting from a heterozygous missense mutation in a family with dominant deaf-mutism and palmoplantar keratoderma. Hum Genet 1998; 103(4): 393-9.

Richard, G., Rouan, F., Willoughby, C. E., Brown, N., Chung, P., Ryynanen, M., Jabs, E. W., Bale, S. J., DiGiovanna, J. J., Uitto, J., Russell, L. Missense mutations in GJB2 encoding connexin-26 cause the ectodermal dysplasia keratitis-ichthyosis-deafness syndrome. Am J Hum Genet 2002; 70: 1341-1348.

Rio C, Dikkes P, Liberman MC, Corfas G. Glial fibrillary acidic protein expression and promoter activity in the inner ear of developing and adult mice. J Comp Neurol. 2002 Jan 7;442(2):156-62.

Roberson DW, Alosi JA, Cotanche DA. Direct transdifferentiation gives rise to the earliest new hair cells in regenerating avian auditory epithelium. J Neurosci Res. 2004 Nov 15;78(4):46171.

Rodríguez-Ballesteros M, Reynoso R, Olarte M, Villamar M, Morera C, Santarelli R, Arslan E, Medá C, Curet C, Völter C, Sainz-Quevedo M, Castorina P, Ambrosetti U, Berrettini S, Frei K, Tedín S, Smith J, Cruz Tapia M, Cavallé L, Gelvez N, Primignani P, Gómez-Rosas E, Martín M, Moreno-Pelayo MA, Tamayo M, Moreno-Barral J, Moreno F, del Castillo I. A multicenter study on the prevalence and spectrum of mutations in the otoferlin gene (OTOF) in subjects with nonsyndromic hearing impairment and auditory neuropathy.Hum Mutat. 2008 Jun;29(6):823-31.

Rous BA, Reaves BJ, Ihrke G, Briggs JAG, Gray SR, Stephens DJ, Banting G, Luzio JP. Role of Adaptor Complex AP-3 in Targeting Wild- Type and Mutated CD63 to Lysosomes. Mol Biol Cell 2002; 13: 1071-1082.

Roux I, Safieddine S, Nouvian R, Grati M, Simmler MC, Bahloul A, Perfettini I, Le Gall M, Rostaing P, Hamard G, Triller A, Avan P, Moser T, Petit C.Otoferlin, defective in a human deafness form, is essential for exocytosis at the auditory ribbon synapse. Cell. 2007 Oct 20;127(2):277-89.

Sage C, Huang M, Karimi K, Gutierrez G, Vollrath MA, Zhang DS, Garcia-Anoveros J, Hinds PW, Corwin JT, Corey DP, Chen ZY. Proliferation of functional hair cells in vivo in the absence of the retinoblastoma protein. Science. 2005 Feb 18;307(5712):1056-8.

Sajan SA, Warchol ME, Lovett M. Toward a systems biology of mouse inner ear organogenesis: gene expression pathways, patterns and network analysis. Genetics 2007; 177(1): 631-53. 
Sakaguchi H, Yaoi T, Suzuki T, Okano H, Hisa Y, Fushiki S. Spatiotemporal patterns of Musashi1 expression during inner ear development. Neuroreport. 2004;15:997-1001.

Sambrook J., Fritsch E.F. \& Maniatis T. Molecular cloning: a laboratory manual. 2a Ed. Cold Spring Harbor Laboratory Press, New York, 1989.

Sartorato EL, Gottardi E, de Oliveira CA, Magna LA, Annichino-Bizzacchi JM, Seixas CA, Maciel-Guerra AT. Determination of the frequency of the 35delG allele in Brazilian neonates. Clin Genet. 2000 Oct;58(4):339-40.

Santos RL, Aulchenko YS, Huygen PL, van der Donk KP, de Wijs IJ, Kemperman MH, Admiraal RJ, Kremer H, Hoefsloot LH, Cremers CW. Hearing impairment in Dutch patients with connexin 26 (GJB2) and connexin 30 (GJB6) mutations. Int J Pediatr Otorhinolaryngol. 2005 Feb;69(2):165-74.

Saumweber T, Weyhersmüller A, Hallermann S, Diegelmann S, Michels B, Bucher D, Funk N, Reisch D, Krohne G, Wegener S, Buchner E, Gerber B. Behavioral and synaptic plasticity are impaired upon lack of the synaptic protein SAP47. J Neurosci 2011; 31(9): 3508-18.

Savary E, Hugnot JP, Chassigneux Y, Travo C, Duperray C, Van De Water T, et al. Distinct population of hair cell progenitors can be isolated from the postnatal mouse cochlea using side population analysis. Stem Cells 2007;25(2):332-9.

Savary E, Sabourin JC, Santo J, Hugnot JP, Chabbert C, Van De Water T, et al. Cochlear stem/progenitor cells from a postnatal cochlea respond to Jagged1 and demonstrate that notch signaling promotes sphere formation and sensory potential. Mech Dev 2008;125(8):674-86.

Schuyler SC, Pellman D.Search, capture and signal: games microtubules and centrosomes play. J Cell Sci. 2001 Jan;114(Pt 2):247-55. Review.

Searle BC. Scaffold: a bioinformatic tool for validating MS/MS-based proteomic studies. Proteomics 2010; 10(6):1265-9.

Seeman P, Sakmaryová I. High prevalence of the IVS $1+1 \mathrm{G}$ to A/GJB2 mutation among Czech hearing impaired patients with monoallelic mutation in the coding region of GJB2. Clin Genet. 2006 May;69(5):410-3

Senn P, Oshima K, Teo D, Grimm C, Heller S. Robust postmortem survival of murine vestibular and cochlear stem cells. J Assoc Res Otolaryngol. 2007 Jun;8(2):194-204.

Shahin H, Walsh T, Sobe T, Lynch E, King MC, Avraham KB, Kanaan M.Genetics of congenital deafness in the Palestinian population: multiple connexin 26 alleles with shared origins in the Middle East. Hum Genet. 2002 Mar;110(3):284-9.

Shaw RM, Fay AJ, Puthenveedu MA, von Zastrow M, Jan YN, Jan LY.Microtubule plus-endtracking proteins target gap junctions directly from the cell interior to adherens junctions. Cell. 2007 Feb 9;128(3):547-60. Erratum in: Cell. 2008 Apr 18;133(2):376.

Shepherd JD, Bear MF.New views of Arc, a master regulator of synaptic plasticity. Nat Neurosci. 2011 Mar;14(3):279-84.

Shiraishi-Yamaguchi Y, Furuichi T.The Homer family proteins. Genome Biol. 2007;8(2):206. Review. 
Silva-Costa SM, Coeli FB, Lincoln-de-Carvalho CR, Marques-de-Faria AP, Kurc M, Pereira T, Pomilio MC, Sartorato EL. Screening for the GJB2 c.-3170 G>A (IVS 1+1 G>A) mutation in Brazilian deaf individuals using multiplex ligation-dependent probe amplification. Genet Test Mol Biomarkers. 2009 Oct;13(5):701-4.

Simader H, Hothorn M, Köhler C, Basquin J, Simos G, Suck D. Structural basis of yeast aminoacyl-tRNA synthetase complex formation revealed by crystal structures of two binary sub-complexes. Nucleic Acids Res 2006; 34(14): 3968-79.

Sirmaci A, Akcayoz-Duman D, Tekin M. The c.IVS1+1G>A mutation in the GJB2 gene is prevalent and large deletions involving the GJB6 gene are not present in the Turkish population. J Genet. 2006 Dec;85(3):213-6.

Smeti I, Savary E, Capelle V, Hugnot JP, Uziel A, Zine A. Expression of candidate markers for stem/progenitor cells in the inner ears of developing and adult GFAP and nestin promoterGFP transgenic mice. Gene Expr Patterns 2011; 11(1-2):22-32.

Smith DB, Johnson KS. Single-step purification of polypeptides expressed in Escherichia coli as fusions with glutathione S-transferase. Gene. 1988 Jul 15;67(1):31-40.

Smith RJH, Hildebrand MS, Van Camp G. Deafness and hereditary hearing loss overview. In: Pagon RA (Ed.). Gene reviews. Seattle: University of Washington, Seattle, 1993-. <http://www.ncbi.nlm.nih.gov/bookshelf/br.fcgi?book=gene\&part=deafness-overview $>$. Acesso em: Junho 2011.

Smith, D.B. \& Johnson, K.S. Single-step purification of polypeptides expressed in Escherichia coli as fusions of glutathione-Stransferase. Gene 1988; 67: 31-40.

Snoeckx RL, Hassan DM, Kamal NM, Van Den Bogaert K, Van Camp G. Mutation analysis of the GJB2 (connexin 26) gene in Egypt. Hum Mutat. 2005 Jul;26(1):60-1.

Sorgen PL, Duffy HS, Sahoo P, Coombs W, Delmar M, Spray DC. Structural changes in the carboxyl terminus of the gap junction protein connexin43 indicates signaling between binding domains for c-Src and zonula occludens-1. J Biol Chem 2004; 279(52): 54695-701.

Spray DC, Ye ZC, Ransom BR. Functional connexin "hemichannels": a critical appraisal. Glia. 2006 Nov 15;54(7):758-73. Review.

Steiner, C. E., Torriani, M., Norato, D. Y. J., Marques-de-Faria, A. P. Spondylocarpotarsal synostosis with ocular findings. Am J Med Genet 2000; 91: 131-134.

Stepp JD, Huang K, Lemmon SK. The yeast adaptor protein complex, ap-3, is essential for the efficient delivery of alkaline phosphatase by the alternate pathway to the vacuole. J Cell Biol 1997; 139(7): 1761-1774

Stern, H. J., Graham, J. M., Jr., Lachman, R. S., Horton, W., Bernini, P. M., Spiegel, P. K., Bodurtha, J., Ives, E. J., Bocian, M., Rimoin, D. L. Atelosteogenesis type III: a distinct skeletal dysplasia with features overlapping atelosteogenesis and oto-palato-digital syndrome type II. Am. J. Med. Genet. 36: 183-195, 1990

Stone JS, Cotanche DA. Hair cell regeneration in the avian auditory epithelium. Int J Dev Biol. 2007;51(6-7):633-47. 
Stone JS, Oesterle EC, Rubel EW. Recent insights into regeneration of auditory and vestibular hair cells. Curr Opin Neurol. 1998 Feb;11(1):17-24. Review.

Stone JS, Rubel EW. Cellular studies of auditory hair cell regeneration in birds. Proc Natl Acad Sci USA 2000;97(22):11714-21.

Stone JS, Shang JL, Tomarev S. cProx1 immunoreactivity distinguishes progenitor cells and predicts hair cell fate during avian hair cell regeneration. Dev Dyn. 2004 Aug;230(4):597614.

Stossel, T.P., Condeelis, J., Cooley, L., Hartwig, J.H., Noegel, A.,Schleicher, M. and Shapiro, S.S. Filamins as integrators of cell mechanics and signalling. Nat Rev Mol Cell Biol 2001; 2: 138-145.

Sugawara M, Corfas G, Liberman MC.Influence of supporting cells on neuronal degeneration after hair cell loss. J Assoc Res Otolaryngol. 2005 Jun;6(2):136-47.

Sun Y, Tang W, Chang Q, Wang Y, Kong W, Lin X. Connexin30 null and conditional connexin26 null mice display distinct pattern and time course of cellular degeneration in the cochlea. J Comp Neurol. 2009 Oct 20;516(6):569-79.

Sundstrom RA, Van Laer L, Van Camp G, Smith RJ. Autosomal recessive nonsyndromic hearing loss. Am J Med Genet. 1999 Sep 24;89(3):123-9. Review.

Stankovic K, Rio C, Xia A, Sugawara M, Adams JC, Liberman MC, Corfas G.J Survival of adult spiral ganglion neurons requires erbB receptor signaling in the inner ear. Neurosci. 2004 Oct 6;24(40):8651-61.

Thalmann R, Henzl MT, Thalmann I. Specific proteins of the organ of Corti. Acta Otolaryngol. 1997 Mar;117(2):265-8.

Tisdale EJ, Azizi F, Artalejo CR. Rab2 utilizes glyceraldehyde-3-phosphate dehydrogenase and protein kinase $\mathrm{C}\{$ iota $\}$ to associate with microtubules and to recruit dynein. J Biol Chem. 2009 Feb 27;284(9):5876-84. Epub 2008 Dec 23.

Tóth T, Kupka S, Haack B, Fazakas F, Muszbek L, Blin N, Pfister M, Sziklai I. Coincidence of mutations in different connexin genes in Hungarian patients. Int J Mol Med. 2007 Sep;20(3):315-21.

Toyofuku T, Yabuki M, Otsu K, Kuzuva T, Hori M, Tada M. Direct association of the gap junction protein connexin-43 with ZO-1 in cardiac myocytes. J Biol Chem 1998; 273(21): 12725:31.

Tristan C, Shahani N, Sedlak TW, Sawa A. The diverse functions of GAPDH: Views from different subcellular compartments. Cell Signal. 2011 Feb;23(2):317-23.

Tritsch NX, Yi E, Gale JE, Glowatzki E, Bergles DE. The origin of spontaneous activity in the developing auditory system. Nature. 2007 Nov 1;450(7166):50-5.

Uehara, DT. Pesquisa de microrrearranjos em genes candidatos a surdez sindrômica e nãosindrômica. Dissertação de Mestrado. Instituto de Biociências da USP. São Paulo. SP. 2010.

Uyguner, O., Tukel, T., Baykal, C., Eris, H., Emiroglu, M., Hafiz, G., Ghanbari, A., Baserer, N., Yuksel-Apak, M., Wollnik, B. The novel R75Q mutation in the GJB2 gene causes autosomal dominant hearing loss and palmoplantar keratoderma in a Turkish family. Clin Genet 2002; 62: 306-309. 
Van Camp G, Smith RJH. Hereditary hearing loss homepage. URL: <http://hereditaryhearingloss.org/>. Acesso em: Julho 2011.

Walsh T, Pierce SB, Lenz DR, Brownstein Z, Dagan-Rosenfeld O, Shahin H, Roeb W, McCarthy S, Nord AS, Gordon CR, Ben-Neriah Z, Sebat J, Kanaan M, Lee MK, Frydman M,King MC, Avraham KB.Genomic duplication and overexpression of TJP2/ZO-2 leads to altered expression of apoptosis genes in progressive nonsyndromic hearing loss DFNA51. Am J Hum Genet. 2010 Jul 9;87(1):101-9.

Wang Y, Chang Q, Tang W, Sun Y, Zhou B, Li H, Lin X. Targeted connexin26 ablation arrests postnatal development of the organ of Corti. Biochem Biophys Res Commun. 2009 Jul 17;385(1):33-7.

Warchol ME, Corwin JT. Regenerative proliferation in organ cultures of the avian cochlea: identification of the initial progenitors and determination of the latency of the proliferative response. J Neurosci. 1996 Sep 1;16(17):5466-77.

Warchol ME, Lambert PR, Goldstein BJ, Forge A, Corwin JT. Regenerative proliferation in inner ear sensory epithelia from adult guinea pigs and humans. Science. $1993 \mathrm{Mar}$ 12;259(5101):1619-22.

Warchol ME. Sensory regeneration in the vertebrate inner ear: differences at the levels of cells and species. Hear Res. 2011 Mar;273(1-2):72-9. Review.

Warchol,M.E.,Corwin,J.T.,1996. Regenerative proliferation in organ cultures of the avian cochlea: identification of the initial progenitors and determination of the latency of the proliferative response.J.Neurosci.16,5466e5477.

White PM, Doetzlhofer A, Lee YS, Groves AK, Segil N. Mammalian cochlear supporting cells can divide and trans-differentiate into hair cells. Nature 2006;441(7096):984-7.

Widera D, Mikenberg I, Kaus A, Kaltschmidt C, Kaltschmidt B. Nuclear Factor-kappaB controls the reaggregation of 3D neurosphere cultures in vitro. Eur Cell Mater 2006;11:7684; discussion 85 .

Wiese C, Rolletschek A, Kania G, Blyszczuk P, Tarasov KV, Tarasova Y, Wersto RP, Boheler KR, Wobus AM. Nestin expression--a property of multi-lineage progenitor cells? Cell Mol Life Sci. 2004 Oct;61(19-20):2510-22. Review.

Wilch E, Azaiez H, Fisher RA, Elfenbein J, Murgia A, Birkenhäger R, Bolz H, Da Silva-Costa SM, Del Castillo I, Haaf T, Hoefsloot L, Kremer H, Kubisch C, Le Marechal C, Pandya A, Sartorato EL, Schneider E, Van Camp G, Wuyts W, Smith RJ, Friderici KH. A novel DFNB1 deletion allele supports the existence of a distant cis-regulatory region that controls GJB2 and GJB6 expression. Clin Genet. 2010 Sep;78(3):267-74.

Wilch E, Zhu M, Burkhart KB, Regier M, Elfenbein JL, Fisher RA, Friderici KH.Expression of GJB2 and GJB6 is reduced in a novel DFNB1 allele. Am J Hum Genet. 2006 Jul;79(1):1749 .

Worley PF, Zeng W, Huang G, Kimd JY, Shin DM, Kimc MS, Yuan JP, Kiselyov K, Muallemc S. Homer proteins in Ca2+ignaling by excitable and non-excitable cells. Cell Calcium 2007; 42: 363-371. 
Xiong WC, Feng X. PYK2 and FAK in osteoclasts. Front Biosci. 2003 Sep 1;8:d1219-26.

Xu X, Francis R, Wei CJ, Linask KL, Lo CW. Connexin 43-mediated modulation of polarized cell movement and the directional migration of cardiac neural crest cells. Development. 2006 Sep;133(18):3629-39.

Yamashita H, Oesterle EC. Induction of cell proliferation in mammalian inner-ear sensory epithelia by transforming growth factor alpha and epidermal growth factor. Proc Natl Acad Sci USA. 1995;92:3152-3155.

Yamasoba T, Kondo K. Supporting cell proliferation after hair cell injury in mature guinea pig cochlea in vivo. Cell Tissue Res. 2006 Jul;325(1):23-31.

Yamasoba,T., Kondo,K. Supporting cell proliferation after hair cell injury in mature guinea pig cochlea in vivo. Cell Tissue Res. 2006.325 , 23e31.

Yerukhimovich MV, Bai L, Chen DH, Miller RH, Alagramam KN. Identification and characterization of mouse cochlear stem cells. Dev Neurosci. 2007;29:251-260.

Yotsumoto S, Hashiguchi T, Chen X, Ohtake N, Tomitaka A, Akamatsu H, Matsunaga K, Shiraishi S, Miura H, Adachi J, Kanzaki T. Novel mutations in GJB2 encoding connexin-26 in Japanese patients with keratitis-ichthyosis-deafness syndrome. Br J Dermatol 2003; 148(4): 649-53.

Yuan Y, Yu F, Wang G, Huang S, Yu R, Zhang X, Huang D, Han D, Dai P. Prevalence of the GJB2 IVS1+1G >A mutation in Chinese hearing loss patients with monoallelic pathogenic mutation in the coding region of GJB2. J Transl Med. 2010 Dec 2;8:127.

Zhai S, Shi L, Wang BE, Zheng G, Song W, Hu Y, Gao WQ. Isolation and culture of hair cell progenitors from postnatal rat cochleae. J Neurobiol. 2005 Dec;65(3):282-93.

Zhang JT, Nicholson BJ. Sequence and tissue distribution of a second protein of hepatic gap junctions, Cx26, as deduced from its cDNA. J Cell Biol 1989; 109 (6 Pt 2): 3391-401.

Zhang Q, Piston DW, Goodman RH. Regulation of corepressor function by nuclear NADH. Science. 2002 Mar 8;295(5561):1895-7

Zhang Y, Tang W, Ahmad S, Sipp JA, Chen P, Lin X. Gap junction-mediated intercellular biochemical coupling in cochlear supporting cells is required for normal cochlear functions. Proc Natl Acad Sci USA. 2005 Oct 18;102(42):15201-6.

Zhang Y, Zhai SQ, Shou J, Song W, Sun JH, Guo W, Zheng GL, Hu YY, Gao WQ. Isolation, growth and differentiation of hair cell progenitors from the newborn rat cochlear greater epithelial ridge. J Neurosci Methods. 2007 Aug 30;164(2):271-9.

Zhao HB. Long-term natural culture of cochlear sensory epithelia of guinea pigs. Neurosci Lett 2001;315(1-2):73-6.

Zhao Y, Zhang J, Li H, Li Y, Ren J, Luo M, Zheng X.An NADPH sensor protein (HSCARG) down-regulates nitric oxide synthesis by association with argininosuccinate synthetase and is essential for epithelial cell viability. J Biol Chem. 2008 Apr 18;283(16):11004-13.

Zheng JL, Gao WQ. Overexpression of Math1 induces robust production of extra hair cells in postnatal rat inner ears. Nat Neurosci 2000;3(6):580-6. 
Zheng JL, Helbig C, Gao WQ. Induction of cell proliferation by fibroblast and insulin-like growth factors in pure rat inner ear epithelial cell cultures. J Neurosci. 1997 Jan 1;17(1):21626.

Ziegler WH, Gingras AR, Critchley DR, Emsley J. Integrin connections to the cytoskeleton through talin and vinculin. Biochem Soc Trans. 2008 Apr;36(Pt 2):235-9. Review.

Zine A, de Ribaupierre F. Replacement of mammalian auditory hair cells. Neuroreport. 1998;9:263-268. 